\title{
Öğretmen Adaylarının Temel Birimler ve Ön Ekler ile İlgili Bilgi Düzeylerinin Belirlenmesi
}

\section{Mustafa Çoramık ${ }^{1}$}

\author{
Erdoğan Özdemir ${ }^{2}$
}

Type/Tür:

Research/Araştırma

Received/Geliş Tarihi:

November 4/4 Kasim 2019

Accepted/Kabul Tarihi: June

24/24 Haziran 2020

Page numbers/Sayfa No: 729 -

754

Corresponding

Author/İletişimden Sorumlu

Yazar:

mustafacoramik@balikesir.ed $\underline{\text { u.tr }}$

\section{$\checkmark$ iThenticate}

This paper was checked for plagiarism using iThenticate during the preview process and before publication. / $\mathrm{Bu}$ çalışma ön inceleme sürecinde ve yayımlanmadan önce iThenticate yazılımı ile taranmıştır.

Copyright $($ C 2017 by Cumhuriyet University, Faculty of Education. All rights reserved.

\section{Öz}

Bir niceliğin büyüklüğünü belirleme işi olan "ölçme" ve bu nicelik cinsinden belirli bir büyüklüğü tanımlayan "birimler", temel bilimler için çok önemlidir. Ölçmeyi standart hale getirmek için Uluslararası Birimler Sistemi (SI) kabul edilmiştir. Bu birim sistemi ile "temel birimler" tanımlanmıştır. Bu araştırmada, fizik, kimya, biyoloji ve fen bilgisi öğretmen adaylarının SI'da yer alan "temel birimler" ve ölçmede kullanılan "ön ekler" ile ilgili bilgi düzeyini belirlemek amaçlanmıştır. Araştırmada nicel araştırma yöntemlerinden biri olan betimsel model kullanılmıştır. Araştırmaya, Türkiye'de yer alan bir üniversitenin eğitim fakültesinin üçüncü ve dördüncü sınıfında öğrenim gören 196 öğretmen adayı katılmıştır. Araştırmada veri toplama aracı olarak araştırmacılar tarafından geliştirilen ve üç açık uçlu sorudan oluşan "Temel Birimler ve Ön Ekler Açık Uçlu Soru Formu" kullanılmıştır. Araştırma verileri "Betimsel İstatistik" ile birlikte "İlişkisiz Örneklemler için Tek Yönlü Varyans Analizi" ve "İlişkisiz Ölçümler için Kruskal Wallis H-Testi" ile analiz edilmiştir. Araştırma sonuçları, öğretmen adaylarının "temel birimler" ile ilgili orta düzeyde, "ön ekler" ile ilgili ise düşük düzeyde başarı gösterdiklerini ifade etmektedir. Ayrıca, fizik ve kimya öğretmen adaylarının "temel birimler" ve "ön ekler" konuları ile ilgili bilgi düzeyinin fen bilgisi ve biyoloji öğretmen adaylarının bu konular ile ilgili bilgi düzeyinden daha yüksek olduğu sonucuna ulaşılmıştır. Son olarak, sınıf düzeyi arttıkça genellikle "temel birimler" ile ilgili bilgi düzeyinin arttığı, "ön ekler" ile ilgili bilgi düzeyinin azaldığ anlaşılmıştır. Araştırma sonuçları, öğretmenlik lisans programları ve laboratuvar eğitimi göz önünde bulundurularak tartışılmış, ölçme ve birim sistemleri ünitesinin öğretmenlik bölümlerindeki öğretimi için çeşitli öneriler sunulmuştur.

Anahtar Kelimeler: Temel birimler, temel büyüklükler, ön ekler, uluslararası birimler sistemi, öğretmen adayları.

\footnotetext{
Suggested APA Citation/Önerilen APA Atıf Biçimi:

Çoramık, M., \& Özdemir, E. (2020). Öğretmen adaylarının temel birimler ve ön ekler ile ilgili bilgi düzeylerinin belirlenmesi. Cumhuriyet International Journal of Education, 9(3), 729-754. http://dx.doi.org/10.30703/cije.642120
}

\footnotetext{
1 Araş. Gör. Dr., Balıkesir Üniversitesi, Matematik ve Fen Bilimleri Eğitimi Bölümü, Balıkesir/Türkiye Res. Asst. Dr., Balıkesir University, Department of Mathematics and Science Education, Balıkesir/Turkey e-mail: mustafacoramik@balikesir.edu.tr ORCID ID: orcid.org/ 0000-0002-3225-633X

2 Dr. Öğr. Üyesi, Sivas Cumhuriyet Üniversitesi, Sağlık Hizmetleri Meslek Yüksekokulu, Sivas/Türkiye Assist. Prof. Dr., Sivas Cumhuriyet University, Vocational School of Health Services, Sivas/Turkey e-mail: erdoganozdemir@cumhuriyet.edu.tr ORCID ID: orcid.org/ 0000-0001-7943-8002
} 


\title{
Determination of Pre-service Teachers' Knowledge Level of "SI" Base Units and Prefixes
}

\begin{abstract}
"Measurement" which is the job of determining the magnitude of a quantity and "units" which define a certain magnitude in terms of quantity are very important for fundamental sciences. An international unit system (SI) has been adopted to standardize measurement. "Base units" are defined in "SI" unit system. In this study, it is aimed to determine the knowledge level of physics, chemistry, biology and science teacher candidates about "base units" and "prefixes". Descriptive model, which is one of the quantitative research methods, was used in the study. A total of 196 students studying at the faculty of education at a university located in Turkey participated in the study. "Base Units and Prefixes Open-ended Questionnaire", which was developed by researchers, consisting of three open-ended questions was used as data collection tool in the research. Research data were analyzed with "descriptive statistics", "One Way Analysis of Variance" and "Kruskal Wallis H Test for Unequal Group Size". The results of the research indicate that the pre-service teachers have a medium level of success in "base units" and a low level of success in "prefixes". In addition, it is concluded that the level of knowledge of physics and chemistry teacher candidates on "base units" and "prefixes" subjects are higher than science and biology teacher candidates. Finally, it is concluded that as the level of grade increases, the level of knowledge about "base units" increases, but the level of knowledge about "prefixes" decreases or does not change. The results of the research have been discussed by considering the undergraduate programs and laboratory education. In addition, various recommendations have been presented for teaching the unit of measurement and unit systems in teaching departments.
\end{abstract}

Keywords: Base units, base quantities, prefixes, international system of units, teacher candidates.

\section{Giriş}

Ölçme, bir niceliğin büyüklüğünü belirleme eylemidir. Kelvin, ölçmenin doğa bilimleri açısından önemini şu şekilde açıklamıştır: "Hakkında konuştuğunuz şeyi ölçebiliyor ve sayılarla ifade edebiliyorsanız, o şey hakkında bir şey biliyorsunuz demektir. Fakat o şeyi rakamlarla ifade edemiyorsanız bilginiz yetersiz ve tatmin edici değildir." Ölçme, sistemlerin özelliklerinin sayılar cinsinden ifade edilmesini ve anlaşılmasını sağlar (Himbert, 2009; Kuhn, 1961). Bu nedenle, doğa bilimleri ölçme ile başlar. Birimler ise bir niceliği ölçmek için o nicelik cinsinden örnek seçilen belli ve değişmez parçalardır. Maxwell ise birimin ölçmedeki önemini şu şekilde açıklamıştır: “Ölçmenin güvenilir olması için iki faktör gereklidir. Bu faktörler ölçülen büyüklüğün sayısal değeri ve birimidir." (Himbert, 2009). Doğa bilimlerinde ölçülen büyüklükler mutlaka bir birim cinsinden ifade edilir.

Ölçme, Milattan Önce 3000 yılında Eski Misır'da ve Mezopotamya'da başlamıştır. Tarihçilere göre bu yıllarda Mısır'da Nil nehri taşıyordu ve tarlalar sular altında kalıyordu. Sular çekildikten sonra insanlar tarlalarının sınırlarını bulma sorunu yaşıyordu. İnsanlar, bu sorunu aşmak için sabit bir kaya parçası veya ağaç tespit etti. Sonra, bir uzunluk birimi kararlaştırdılar. Tarla sınırı ile kaya veya ağaç parçası arasındaki uzaklıkta, bu birim uzunluktan kaç tane olduğu belirlenerek kayıt altında alındı (Karaoğlu, 2015). Ölçmenin doğayı anlamadaki başarısı ve ticarette sağladı̆̆ı kolaylıklar yaygınlaşmasını sağlamıştır. Dünyanın farklı bölgelerindeki insanlar, birbirinden bağımsız olarak işlerine yarayacak birçok birim tanımlamıştır. Birimlerin çeşitliliği ve standardize olmaması aynı büyüklüğün farklı ölçülmesine 
neden olmaktaydı. Bu durum, bilimde ve ticarette sorun oluşturmaktaydı. On dokuzuncu yüzyılda sanayi devrimi ile birlikte tüm dünyada ekonomik, bilimsel ve teknik gelişmeler yaşandı (Tunzelmann, 2003). Bu durum, birimlerdeki çeşitliliğin azaltılmasını ve birimlerin standardize edilmesini zorunlu hale getirdi. 1960 yılında gerçekleştirilen “Ölçüler ve Ağırlıklar” konferansında Uluslararası Birimler Sistemi (SI) kabul edildi (BIPM, 2006) ve ölçme birimleri resmi bir statü kazandı (Davis, 2003). Günümüzde, bu birim sisteminin birçok ülke tarafından kabul görmesi ile birlikte aynı büyüklük farklı ülkelerde farklı insanlar tarafından eşit ölçülebilmektedir (Koray, Özdemir ve Tatar, 2005).

Uluslararası Birimler Sistemi, yedi temel birimden oluşmaktadır. Bu birimler; zaman (saniye, "s"), uzunluk (metre, "m"), kütle (kilogram, "kg"), elektrik akımı (amper, “A"), sıcaklık (kelvin, "K"), 1şık şiddeti (kandela, "cd") ve madde miktarı (mol)'dır. Bu birimlerden ilk üç tanesi, bir fiziksel büyüklüğün tüm mekanik özelliklerini belirlemek için yeterlidir. Diğer birimler ise sırası ile elektrik, sıcaklık, 1şık ve maddenin atom yapısı ile ilgilidir. Uluslararası Birimler Sistemi sayesinde tüm birimler standart hale getirilmiştir (Mohr ve Taylor, 2000). Türetilmiş birimler ise temel birimlerin bir araya gelmesi ile oluşmuştur. Bu nedenle, Uluslararası Birimler Sistemindeki temel birimlerin standardize edilmesi tüm birimlerin standardize edilmesini sağlamaktadır.

SI'da büyüklüklerin bilimsel gösteriminde sayılar ve birimler kullanılır. Büyüklükleri ifade etmek için kullanılan sayılar ise üstkatlar ve askatlar ile ifade edilir. Üstkat ve askatlar “ön ekler” olarak adlandırılır. Örneğin, 1000 gram ifadesi 1 kilogram şeklinde yazılabildiği gibi 1 metre de $100 \mathrm{~cm}$ şeklinde yazılabilir (Keller, Gettys ve Skove, 2005). Konuşma dilinde kolaylık sağlaması için ise 10'un katları şeklinde yazılan bölüm "kilo", "mega", "giga", "tera" olarak üstkatlar veya "santi", "mili", "mikro" ve "nano" olarak askatlar ile ifade edilebilir. Bu sayede $1.10^{3}$ metre olarak ifade edilen bir uzunluk 1 kilometre şeklinde söylenebilir.

Fizik, kimya ve biyoloji bilimlerinin anlaşılabilmesi için ölçmenin ve birimlerin anlaşılması bir ön koşul özelliği sergilemektedir. Bir başka ifade ile doğa bilimleri için ölçme ve birim sistemleri önemlidir (Özdemir, 2008). Bu nedenle fizik kitapları "Ölçme ve Birim Sistemleri" ünitesi ile başlamaktadır (Keller, Gettys ve Skove, 2005; Serway ve Beichner, 2002; Karaoğlu, 2015). Ölçme ve birim sistemleri temel bilimlerin öğretimi için bir ön koşul özelliği sergilemesine rağmen alanyazında bu konu ile ilgili öğretim araştırmalarına (Bulut, 1988; Aydoğan, Güneş ve Gülçiçek, 2003; Bragg ve Outhred, 2004; Ünsal ve Güneş, 2004; Koray, Özdemir ve Tarar, 2005; Yıldırım ve İlhan, 2007; Kalın ve Arıkıl, 2010; Şişman ve Aksu, 2016) az sayıda rastlanmıştır.

Şişman ve Aksu (2016), ilköğretim öğrencilerin uzunluk, alan ve hacim ile ilgili kavram yanılgılarını belirlemek için bir araştırma gerçekleştirmiştir. Araştırmada öğrencilerin uzunluk ölçmek için kullanılan bir aracın mutlaka $30 \mathrm{~cm}$ uzunluğunda olması gerektiğini düşündükleri, uzunluğu ölçülen cismin ölçme aracından daha kısa olması gerektiğini belirttikleri belirlenmiştir. Ayrıca bu araştırmada, öğrencilerin santimetre mertebesindeki bir cetvel ile metre mertebesindeki cisimlerin ölçülemeyeceğini düşündükleri ifade edilmiştir.

Bragg ve Outhred (2004)'in ilköğretim öğrencileri ile yaptığı bir araştırmada ise öğrencilerin cetvel ile uzunluk ölçümü sırasında uygun olmayan birimleri 
kullandıkları tespit edilmiştir. Bu araştırmalarda elde edilen bulgular öğrencilerin ölçmeyi kavramsal olarak anlamadıklarını, ölçme ile ilgili gözlem ve deneyimlerinden yola çıkarak bazı ezber bilgiler oluşturduklarını göstermektedir. Öğrencilerin ölçmeyi kavramsal olarak anlamakta güçlük çekmelerinde ders kitaplarının ölçmeyi yüzeysel olarak tanımlamasının etkisi olduğu iddia edilebilir. Ünsal ve Güneş (2004), lise 1. sınıf fizik ders kitabını bilimsel içerik, eğitsel tasarım, kitap düzeni, bilgi eksiklikleri ve dil anlatım yönünden incelemiştir. Bu kitapta kilogram şu şekilde tanımlanmıştır: "1 kilogram milletlerarası kilogram prototipinin kütlesine eşittir". Fakat kilogram prototipinin özelliklerinden söz edilmemiştir. Yine bu kitapta hareket konusunda bir problemin çözümünde yer değiştirme " $\Delta x=-4$ " olarak ifade edilmiştir. Fakat birimi yazılmamıştır.

Araştırmalar, öğrencilerin ölçmeyi kavramsal olarak anlamada güçlük çekmelerinin yanı sıra birimleri çevirmede de güçlük çektiklerini göstermektedir. Bulut (1988), temel eğitim ve ortaöğretim öğrencilerinin birim çevirme becerilerini ölçmüştür. Araştırma bulgularına göre öğrenciler lirayı kuruşa çevirmede güçlük çekmemektedir. Fakat metrekareyi santimetrekareye çevirmede güçlük çekmektedir. Kalın ve Arıkıl (2010) ise üniversite düzeyindeki öğrencilerinde ilköğretim ve ortaöğretim düzeyindeki öğrenciler gibi birim çevirme hataları yaptığını ifade etmiştir. Araştırmada öğrencilerin " $50 \mathrm{~mL}=0.005 \mathrm{~L}$ " gibi birim çevirme hataları yaptıkları belirlemiştir.

Öğrenciler, birimlerin önemini kavrayamamaktadır ve birimleri etkin kullanamamaktadır. Yıldırım ve İlhan (2007), lise öğrencileri ile gerçekleştirdiği bir araştırmada öğrencilerin birimlerin önemli olduğunu ifade etmelerine rağmen sınavlarda birim yazmadiklarında puanlarının kesilmemesi gerektiğini düşündüklerini ifade etmiştir. Ayrıca, araştırmada öğrencilerin hatırlayamadıkları formülleri bulma konusunda birimlerden yararlanamadıkları vurgulanmıştır.

Öğrencilerin sahip olduğu kavram yanılgıları ölçme ve birim sistemleri ile ilgili öğrenmelerini etkilemektedir. Koray, Özdemir ve Tarar (2005), ilköğretim öğrencilerinin kütle ve ağırlık ile ilgili kavram yanılgılarını belirlemek için bir araştırma gerçekleştirmiştir. Bu araştırmada, ilköğretim öğrencilerinin kütlenin ve ağırlığın birimlerini ve bu nicelikleri ölçmek için kullanılan ölçme araçlarını birbiri ile karıştırdıkları sonucuna ulaşılmıştır. Ayrıca, öğrencilerin temel ve türetilmiş fiziksel nicelikler ile bu niceliklerin birimleri konusunda kavram yanılgılarına sahip oldukları belirtilmiştir. Öğrencilerin kavram yanılgılarının ölçme ve birim sistemleri ile ilgili öğrenmeyi etkilediği bir başka araştırmada daha ifade edilmiştir. Aydoğan, Güneş ve Gülçiçek (2003), lise ve üniversite öğrencilerinin 1sı ve sıcaklık konusundaki kavram yanılgılarını ortaya çıkarmak için bir araştırma yapmıştır. Araştırmada öğrencilerin ısı biriminin yalnızca kalori olduğunu ifade ettikleri belirlenmiştir. Ayrıca bu araştırmada öğrencilerin ısıyı ve sıcaklığı aynı birimlerle ifade ettiği sonucuna ulaşılmıştır.

Alanyazında yer alan ölçme ve birim sistemleri ile ilgili araştırmalar bir bütün olarak ele alındığında öğrencilerin bu ünite ile ilgili yaşadıkları öğrenme güçlükleri şu başlıklar altında gruplanabilir; ölçme kavramı ile ilgili kavramsal öğrenme güçlüğü, birim çevirme güçlüğü, birimlerin önemini kavrama ve etkin kullanma güçlüğü, ölçme ve birim sistemleri için kavram yanılgılarından kaynaklanan öğrenme güçlüğü.

Öğrencilerin ölçme ve birim sistemleri ünitesi ile ilgili yaşadıkları bu öğrenme güçlüklerinin giderilmesi için fizik, kimya, biyoloji ve fen bilgisi öğretmenlerinin bu 
ünite ile ilgili yeterli bilgiye sahip olmaları gerekmektedir. Bu nedenle bu araştırmada, üniversitede öğrenim gören fizik, kimya, biyoloji ve fen bilgisi öğretmen adaylarının Uluslararası Birimler Sistemimde yer alan "temel birimler" ve “ön ekler" ile ilgili bilgi düzeylerini belirlemek amaçlanmıştır. Araştırmanın amacı doğrultusunda şu sorulara yanıt aranmıştır; (i) Öğretmen adaylarının "temel birimler" ve "ön ekler" konusunda bilgi düzeyleri nedir? (ii) Üçüncü sınıfta öğrenim gören öğretmen adaylarının bölümlerine göre "temel birimler" ve "ön ekler" konusunda bilgi düzeyleri arasında fark var mıdır? (iii) Dördüncü sınıfta öğrenim gören öğretmen adaylarının bölümlerine göre "temel birimler" ve "ön ekler" konusunda bilgi düzeyleri arasında fark var midır? (iv) Üçüncü ve dördüncü sınıfta öğrenim gören aynı bölümdeki öğretmen adaylarının "temel birimler" ve “ön ekler" konusunda bilgi düzeyleri arasinda fark var midir?

\section{Yöntem}

$\mathrm{Bu}$ araştırmada, fizik, kimya, biyoloji ve fen bilgisi öğretmen adaylarının ölçme ve birim sistemleri ile ilgili bilgi düzeyleri araştırılmıştır. Araştırma modeli olarak nicel araştırma yöntemlerinden biri olan betimsel model kullanılmıştır. Betimsel modelin kullanıldı ğı araştırmalarda amaç olguları tanımlamak ve olguların ayırıcı niteliklerini belirlemektir (Nassaji, 2015). Araştırmada veri toplama aracı olarak "Temel Birimler ve Ön Ekler Açık Uçlu Soru Formu" kullanılmıştır. Öğrencilerin vermiş olduğu yanıtlar betimsel istatistik ve fark testleri kullanılarak analiz edilmiştir.

\section{Çalışma Grubu}

Araştırmanın örneklemi belirlenirken amaçsal örnekleme yöntemlerinden ölçüt örnekleme tercih edilmiştir. Bu tür örnekleme yönteminde gözlem birimleri belli niteliklere sahip olan kişiler, olaylar ya da durumlardan seçilir. Örneklem için belirlenen ölçütleri sağlayan birimler örnekleme dâhil edilirler (Büyüköztürk, Çakmak, Akgün, Karadeniz ve Demirel, 2010). Bu araştırmada, örneklem belirlemek için iki ölçüt belirlenmiştir. İlk ölçüt şu şekilde tanımlanmıştır; öğrenciler üniversite 3 . veya 4. sınıfta öğrenim görmelidir ve araştırmaya gönüllü olarak katılmalıdır. İkinci ölçüt olarak ise öğrenciler alanları ile ilgili temel dersleri ve bu derslerin laboratuvarlarını başarı ile tamamlamış olmalıdır.

Araştırmanın örneklemini Türkiye'de bir üniversitenin eğitim fakültesinde 2018-2019 güz yarıyılında öğrenim gören 196 üçüncü ve dördüncü sınıf öğretmenlik bölümü öğrencisi oluşturmuştur. Öğretmen adaylarının bölümlere ve sınıflara göre dağılımı Tablo 1'de yer almaktadır.

Tablo 1

Örneklemin Öğrenim Görülen Bölüm ve Sınıf Düzeyine göre Frekans Dă̆ılımı

\begin{tabular}{lcclcc}
\hline Bölüm & Sınıf & f & Bölüm & Sınıf & f \\
\hline Fizik Öğretmenliği & 3 & 19 & Biyoloji Ö̆gretmenliği & 3 & 18 \\
& 4 & 15 & & 4 & 17 \\
Kimya Öğretmenliği & 3 & 16 & Fen Bilgisi Öğretmenliği & 3 & 50 \\
& 4 & 16 & & 4 & 45 \\
\hline
\end{tabular}




\section{Veri Toplama Araçları}

Araştırmada, veri toplama aracı olarak araştırmacılar tarafından geliştirilen "Temel Birimler ve Ön Ekler Açık Uçlu Soru Formu" kullanılmıştır (Ek A). Veri toplama aracı geliştirilirken öncelikle bir taslak form oluşturulmuştur. Taslak form araştırmacılar dışındaki iki fizik eğitimi ve bir fen bilgisi eğitimi uzmanı tarafından incelenmiştir. Bu inceleme sonucuna göre revize edilen form 24 fen bilgisi öğretmenliği öğrencisine uygulanmıştır. Öğrencilerin vermiş olduğu yanıtlar göz önünde bulundurularak taslak form düzenlenmiş ve son haline getirilmiştir. Form, üç soru içermektedir. Formda yer alan birinci soruda öğrencilere Uluslararası Birimler Sisteminde yer alan yedi temel büyüklügüun adları verilmiştir. Öğrencilerden bu temel büyüklüklerin sembollerini, birim adlarını ve birimlerinin sembollerini yazmaları istenmiştir. Formda yer alan ikinci soruda öğrencilere ön eklerle ilgili 12 çarpan verilmiştir. Öğrencilerden bu çarpanların adlarını ve sembollerini yazmaları istenmiştir. Formda yer alan üçüncü soruda öğrencilere ön eklerin adları verilmiştir. Öğrencilerden bu ön eklerin çarpanlarını ve sembollerini yazmaları istenmiştir. Tüm sorular ayrı ayrı uygulanmış ve bu sayede 2. ve 3. soruların birbirinden bağımsız yanıtlanması sağlanmıştır.

\section{Verilerin Analizi}

"Temel Birimler ve Ön Ekler Açık Uçlu Soru Formu” nda yer alan sorulardaki her bir doğru yanıt " 1 " her bir yanlış yanıt ise " 0 " puan olarak puanlanmıştır. Bu durumda, birinci sorudan alınabilecek en yüksek puan 21'dir. İkinci ve üçüncü sorulardan alınabilecek en yüksek puanlar ise $24^{\prime}$ tür. Buna göre puanlanan veriler SPSS 22.0 paket programına aktarılmıştır. Verilerin analizinde, ilk olarak betimsel istatistik kullanılmıştır. Öğretmen adaylarının ortalama puanları, standart sapmaları hesaplanmış ve sonuçlar Tablo 2'ye uygun olarak değerlendirilmiştir.

Tablo 2

Sorulara Göre Başan Düzeyi için Kullanılan Ölçütler

\begin{tabular}{lccc}
\hline Soru Numarası & Yüksek Başarı & Orta Düzey Başarı & Düşük Başarı \\
\hline 1 & $15-21$ & $8-14$ & $0-7$ \\
$2 / 3$ & $17-24$ & $9-16$ & $0-8$ \\
\hline
\end{tabular}

Verilerin analizinde, ikinci olarak ortalamalar arasındaki farkları analiz edebilmek için fark testlerinden yararlanılmıştır. Araştırmaya katılan her bir grubun büyüklüğünün 50 ve daha az olması nedeni ile normallik testi olarak "Shapiro-Wilk Testi" kullanılmıştır (Büyüköztürk, 2007). Bu testin sonuçlarına göre soru formunun birinci sorusu ile ilgili yanıtlar normal dağılım göstermektedir. Fakat ikinci ve üçüncü soru ile ilgili yanıtlar normal dağılım göstermemektedir. Bu nedenle, birinci sorunun analizinde "İlişkisiz Örneklemler için Tek Yönlü Varyans Analizi" (ANOVA) uygulanmıştır. Bu analiz sonucunda ise gruplar arasındaki farkın hangi grup lehine olduğunu belirlemek için "Scheffe Çoklu Karşılaştırma Tekniği" uygulanmıştır. İkinci ve üçüncü soru için ise "İlişkisiz Ölçümler için Kruskal Wallis H-Testi” yapılmıştır. Bu analiz sonucunda, gruplar arasındaki farkın hangi grup lehine olduğunu belirlemek için ise "Mann Whitney-U” testi uygulanmıştır. 


\section{Bulgular}

Aşağıda öğretmen adaylarının ortalama puanları ile üçüncü ve dördüncü sınıfta öğrenim gören öğretmen adaylarının ortalama puanları arasındaki karşılaştırmalara yer verilmiştir.

\section{Öğretmen Adaylarının Testten Aldıkları Ortalama Puan ve Standart Sapma Sonuçları}

Üçüncü ve dördüncü sınıfta öğrenim gören öğretmen adaylarının testte yer alan her bir sorudan aldıkları ortalama puanlar ve standart sapma değerleri Tablo 3'te yer almaktadir.

Tablo 3

Öğretmen Adaylarının Sorulara Göre Puan Ortalamaları ve Standart Sapma Değerleri

\begin{tabular}{|c|c|c|c|c|c|c|c|c|}
\hline \multirow[b]{2}{*}{ Bölüm } & \multirow[b]{2}{*}{ Sinif } & \multirow[b]{2}{*}{$\mathrm{n}$} & \multicolumn{2}{|c|}{ Soru 1} & \multicolumn{2}{|c|}{ Soru 2} & \multicolumn{2}{|c|}{ Soru 3} \\
\hline & & & $\begin{array}{l}\text { Ort. } \\
\text { Puan }\end{array}$ & s.s & $\begin{array}{l}\text { Ort. } \\
\text { Puan }\end{array}$ & s.s & $\begin{array}{l}\text { Ort. } \\
\text { Puan }\end{array}$ & s.s \\
\hline \multirow[t]{3}{*}{ Biyoloji Öğretmenliği } & 3 & 18 & 7.444 & 3.014 & 0.000 & 0.000 & 3.611 & 2.810 \\
\hline & 4 & 17 & 4.411 & 2.647 & 0.000 & 0.000 & 2.411 & 2.152 \\
\hline & $3 / 4$ & 35 & 5.928 & & 0.000 & & 3.011 & \\
\hline \multirow[t]{3}{*}{ Fizik Öğretmenliği } & 3 & 19 & 11.210 & 3.425 & 2.421 & 5.699 & 8.578 & 6.039 \\
\hline & 4 & 15 & 13.866 & 4.323 & 2.066 & 2.051 & 3.333 & 2.968 \\
\hline & $3 / 4$ & 34 & 12.538 & & 2.244 & & 5.956 & \\
\hline \multirow[t]{3}{*}{ Kimya Öğretmenliği } & 3 & 16 & 10.437 & 4.381 & 4.500 & 6.077 & 10.187 & 5.729 \\
\hline & 4 & 16 & 10.562 & 3.424 & 1.687 & 3.910 & 7.125 & 3.480 \\
\hline & $3 / 4$ & 32 & 10.500 & & 3.094 & & 8.656 & \\
\hline \multirow[t]{3}{*}{ Fen Bilgisi Öğretmenliği } & 3 & 50 & 8.460 & 3.124 & 0.540 & 1.417 & 3.860 & 3.714 \\
\hline & 4 & 45 & 11.111 & 4.216 & 0.577 & 1.389 & 3.844 & 2.938 \\
\hline & $3 / 4$ & 95 & 9.786 & & 0.559 & & 3.852 & \\
\hline Genel & $3 / 4$ & 196 & 9.688 & & 2.669 & & 5.369 & \\
\hline
\end{tabular}

Tablo 3'te yer alan sonuçlar, Tablo 2' de yer alan başarı düzeyi ölçütlerine göre analiz edildiğinde öğretmen adaylarının genel ortalama olarak soru 1 için orta düzeyde, soru 2 ve soru 3 için ise düşük düzeyde başarı gösterdikleri anlaşılmaktadır. Ayrıca, Tablo 3'teki sonuçlardan, soru 1 için dördüncü sınıfta öğrenim gören öğretmen adaylarının üçüncü sınıfta öğrenim gören öğretmen adaylarına göre biyoloji öğretmenliği hariç daha başarılı olduğu anlaşılmaktadır. Öğretmen adaylarının ortalama puanları incelendiğinde soru 2 ve soru 3 için sınıf düzeyi arttıkça ortalama puanların azaldığı veya sabit kaldığı (fen bilgisi öğretmenliği soru 2 hariç) anlaşılmaktadir.

\section{Normallik Testi Sonuçları}

Verilerin analizinde ilk olarak normallik testi yapılmıştır. Bölümlere, sınıflara ve testte yer alan sorulara göre elde edilen "Shapiro-Wilk Testi" sonuçları Tablo 4'te yer almaktadir. 
Tablo 4

"Shapiro-Wilk Testi" Sonuçları

\begin{tabular}{|c|c|c|c|c|c|}
\hline \multirow[t]{2}{*}{ Bölüm } & \multirow[t]{2}{*}{ Sinif } & \multirow{2}{*}{ Soru } & \multicolumn{3}{|c|}{ Shapiro-Wilk } \\
\hline & & & İstatistik & s.d & $\mathrm{p}$ \\
\hline \multirow{6}{*}{$\begin{array}{l}\text { Biyoloji } \\
\text { Öğretmenliği }\end{array}$} & \multirow{3}{*}{3} & 1 & .943 & 18 & $.332^{*}$ \\
\hline & & $2^{* *}$ & - & - & - \\
\hline & & 3 & .872 & 18 & 019 \\
\hline & \multirow{3}{*}{4} & 1 & .952 & 17 & $.483^{*}$ \\
\hline & & $2^{* *}$ & - & - & - \\
\hline & & 3 & .886 & 17 & .040 \\
\hline \multirow{6}{*}{$\begin{array}{l}\text { Fizik } \\
\text { Öğretmenliği }\end{array}$} & \multirow{3}{*}{3} & 1 & .957 & 19 & $.509^{*}$ \\
\hline & & 2 & 497 & 19 & .000 \\
\hline & & 3 & .933 & 19 & $.195^{*}$ \\
\hline & \multirow{3}{*}{4} & 1 & .931 & 15 & $284^{*}$ \\
\hline & & 2 & .844 & 15 & .014 \\
\hline & & 3 & .831 & 15 & .009 \\
\hline \multirow{6}{*}{$\begin{array}{l}\text { Kimya } \\
\text { Öğretmenliği }\end{array}$} & \multirow{3}{*}{3} & 1 & .948 & 16 & $.462^{*}$ \\
\hline & & 2 & .772 & 16 & .001 \\
\hline & & 3 & .978 & 16 & $.950^{*}$ \\
\hline & \multirow{3}{*}{4} & 1 & .976 & 16 & $.930^{*}$ \\
\hline & & 2 & .500 & 16 & .000 \\
\hline & & 3 & .899 & 16 & $.077^{*}$ \\
\hline \multirow{6}{*}{$\begin{array}{l}\text { Fen Bilgisi } \\
\text { Öğretmenliği }\end{array}$} & \multirow{3}{*}{3} & 1 & .956 & 50 & $.058^{*}$ \\
\hline & & 2 & .444 & 50 & .000 \\
\hline & & 3 & .866 & 50 & .000 \\
\hline & \multirow{3}{*}{4} & 1 & .968 & 45 & $.243^{*}$ \\
\hline & & 2 & .473 & 45 & .000 \\
\hline & & 3 & .930 & 45 & .010 \\
\hline
\end{tabular}

${ }^{*} \mathrm{p}>.05$,

** Doğru yanıt veren öğretmen adayı yoktur dolayısı ile hesaplama yapılamamıştır.

Tablo 4'ten elde edilen sonuçlara göre bölümlerde yer alan tüm sınıfların Soru 1 'den aldıkları puanlar normal dağılım göstermektedir ( $p>.05)$. Diğer sorular için ise soru bazında tüm sınıfları ve bölümleri kapsayan böyle bir sonuç elde edilememiştir. Sonuç olarak, Soru 1'den elde edilen puanların sınıf bazında bölümler arasında karşılaştırılmasında parametrik testlerden "İlişkisiz Örneklemler için Tek Yönlü Varyans Analizi (One-Way ANOVA)", Soru 2' nin ve Soru 3'ün sınıf bazında bölümler arasında karşılaştırılmasında ise parametrik olmayan testlerden "İlişkisiz Ölçümler için Kruskal Wallis H-Testi" kullanılmasına karar verilmiştir.

Aşağıdaki bölümlerde üçüncü sınıfta öğrenim gören öğretmen adaylarının ve dördüncü sınıfta öğrenim gören öğretmen adaylarının soru formunda yer alan her bir sorudan aldıkları puanlar ayrı ayrı karşılaştırılmıştır.

Üçüncü Sınıfta Öğrenim Gören Öğretmen Adaylarının Puanların Karşılaştırılması Aşağıda, üçüncü sınıfta öğrenim gören öğretmen adaylarının soru formunda yer alan her bir sorudan aldıkları puanların karşılaştırmalarına yer verilmiştir.

Üçüncü sınıfta öğrenim gören öğretmen adaylarının soru 1'e ilişkin bulguları. Üçüncü sınıfta öğrenim gören farklı bölümlerdeki öğretmen adaylarının Soru 1'den aldıkları puanların karşılaştırılması için uygulanan İlişkisiz Örneklemler 
için Tek Yönlü Varyans Analizi (One-Way ANOVA) sonuçları Tablo 5'te yer almaktadir.

Tablo 5

Soru 1 için "İlişkisiz Örneklemler için Tek Yönlü Varyans Analizi" Sonuçlarn

\begin{tabular}{lccccc}
\hline & Kareler Toplamı & s.d & Kareler Ortalaması & F & p \\
\hline Gruplar Arası & 183.069 & 3 & 61.023 & 5.337 & .002 \\
Grup İçi & 1131.960 & 99 & 11.434 & & \\
Toplam & 1315.029 & 102 & & & \\
\hline
\end{tabular}

Tablo 5'te yer alan sonuçlar incelendiğinde, bölümlerin üçüncü sınıflarında öğrenim gören öğretmen adaylarının Soru 1'den aldıkları puanlar arasında istatistiksel olarak anlamlı bir farklılık olduğu anlaşılmaktadır $(\mathrm{F}(3,99)=5.337, \mathrm{p}<.05)$. İlişkisiz Örneklemler için Tek Yönlü Varyans Analizi ile ortaya çıkan anlamlı farklılığın hangi bölümler arasında olduğunu belirlemek için "Post-Hoc Analiz Tekniği" uygulanmıştır. Öncelikle, "Levene Testi" ile grup dağılımlarının varyanslarının homojen olup olmadığı sınanmıştır ve varyansların homojen olduğu belirlenmiştir ( $>$.05). Varyansların homojen olması durumunda yaygınlıkla kullanılan ve alpha tipi hataya karşı duyarlı olan "Scheffe Çoklu Karşılaştırma Tekniği" kullanılmıştır. Bu analizin sonuçları Tablo 6' da yer almaktadır.

Tablo 6

Soru 1 için "Post-HocScheffe Testi" Sonuçlan

\begin{tabular}{llcc}
\hline Bölüm (i) & Bölüm (j) & Ortalama Farki & $\mathrm{p}$ \\
\hline Biyoloji Öğretmenliği & Fizik Öğretmenliği & -3.766 & $.012^{*}$ \\
& Kimya Öğretmenliği & -2.993 & .091 \\
& Fen Bilgisi Öğretmenliği & -1.015 & .755 \\
\hline Fizik Öğretmenliği & Biyoloji Öğretmenliği & 3.766 & $.012^{*}$ \\
& Kimya Öğretmenliği & .773 & .929 \\
& Fen Bilgisi Öğretmenliği & 2.750 & $.033^{*}$ \\
\hline Kimya Öğretmenliği & Biyoloji Öğretmenliği. & 2.993 & .091 \\
& Fizik Öğretmenliği & -.773 & .929 \\
& Fen Bilgisi Öğretmenliği & 1.977 & .253 \\
\hline Fen Bilgisi Öğretmenliği & Biyoloji Öğretmenliği & 1.015 & .755 \\
& Fizik Öğretmenliği & -2.750 & $.033^{*}$ \\
& Kimya Öğretmenliği & -1.977 & .253 \\
\hline
\end{tabular}

${ }^{*} \mathrm{p}<.05$

Tablo 6 incelendiğinde, soru 1 için üçüncü sınıfta öğrenim fizik $(\bar{x}=11.210$, s.s=3.425) ve biyoloji ( $\bar{x}=7.444$, s.s=3.014) öğretmen adayları arasında fizik öğretmen adayları lehine anlamlı bir farklılık belirlenmiştir. Ayrıca fizik $(\bar{x}=11.210, \mathrm{s.s}=3.425)$ ve fen bilgisi $(\bar{x}=8.460$, s.s=3.124) öğretmen adayları arasında yine fizik öğretmen adayları lehine anlamlı farklılık tespit edilmiştir.

Üçüncü sınıfta öğrenim gören öğretmen adaylarının soru 2'ye ilişkin bulguları. Üçüncü sınıfta öğrenim gören farklı bölümlerdeki öğretmen adaylarının Soru 2' den aldıkları puanların karşılaştırılması için uygulanan "İlişkisiz Ölçümler için Kruskal Wallis H-Testi" sonuçları Tablo 7' de verilmiştir. 
Tablo 7

Soru 2 için "Kruskal Wallis Testi" Sonuçları

\begin{tabular}{lccccc}
\hline Bölüm & $\mathrm{n}$ & Stra ort. & s.d & $\mathrm{X}^{2}$ & $\mathrm{p}$ \\
\hline Biyoloji Öğretmenliği & 18 & 38.50 & 3 & 20.478 & .000 \\
Fizik Öğretmenliği & 19 & 55.47 & & & \\
Kimya Öğretmenliği & 16 & 72.81 & & & \\
Fen Bilgisi Öğretmenliği & 50 & 48.88 & & & \\
Toplam & 103 & & & & \\
\hline
\end{tabular}

Tablo 7'de yer alan sonuçlar fizik, kimya, biyoloji ve fen bilgisi öğretmen adaylarının Soru 2'den aldıkları puanlar arasında anlamlı bir farklılık olduğunu göstermektedir $(X 2$ (s.d=3, n=103) $=20.478, p<.05)$. Bölümler arasında ortaya çıan anlamlı farklılığın hangi bölümler lehine olduğunu belirlemek için grupların ikili kombinasyonları üzerine "Mann Whitney-U Testi" uygulanmıştır. Bu testten elde edilen sonuçlar Tablo 8' de yer almaktadır.

Tablo 8

Soru 2 için "Mann Whitney-U Testi" Sonuçlarn

\begin{tabular}{llllll}
\hline Bölüm & $\mathrm{n}$ & Sıra Ortalamas1 & S1ra Toplami & $\mathrm{U}$ & $\mathrm{p}$ \\
\hline Biyoloji Öğretmenliği & 18 & 16.00 & 288.00 & 117.000 & $.011^{*}$ \\
Fizik Öğretmenliği & 19 & 21.84 & 415.00 & & \\
\hline Biyoloji Öğretmenliği & 18 & 12.50 & 225.00 & 54.000 & $.000^{*}$ \\
Kimya Öğretmenliği & 16 & 23.13 & 370.00 & & \\
\hline Biyoloji Öğretmenliği & 18 & 29.00 & 522.00 & 351.000 & $.032^{*}$ \\
Fen Bilgisi Öğretmenliği & 50 & 36.48 & 1824.00 & & \\
\hline Fizik Öğretmenliği & 19 & 15.45 & 293.50 & 103.500 & .080 \\
Kimya Öğgretmenliği & 16 & 21.03 & 336.50 & & \\
\hline Fizik Öğretmenliği & 19 & 38.18 & 725.50 & 414.500 & .282 \\
Fen Bilgisi Öğretmenliği & 50 & 33.79 & 1689.50 & & \\
\hline Kimya Öğretmenliği & 16 & 45.66 & 730.50 & 205.500 & $.000^{*}$ \\
Fen Bilgisi Öğretmenliği & 50 & 29.61 & 1480.50 & & \\
\hline
\end{tabular}

${ }^{*} \mathrm{p}<.05$

Tablo 8 incelendiğinde üçüncü sınıfta öğrenim gören biyoloji ve fizik öğretmen adayları arasında fizik; biyoloji ve kimya öğretmen adayları arasında kimya; biyoloji ve fen bilgisi öğretmen adayları arasında fen bilgisi; kimya ve fen bilgisi öğretmen adayları arasında kimya öğretmen adayları lehine anlamlı farklılık tespit edilmiştir.

Üçüncü sınıfta öğrenim gören öğretmen adaylarının soru 3'e ilişkin bulguları. Üçüncü sınıfta öğrenim gören farklı bölümlerdeki öğretmen adaylarının Soru 3'ten aldıkları puanların karşılaştııılması için uygulanan İlişkisiz Ölçümler için Kruskal Wallis H-Testi sonuçları Tablo 9' da yer almaktadır. 
Tablo 9

Soru 3 için "Kruskal Wallis Testi" Sonuçları

\begin{tabular}{lccccc}
\hline Bölüm & $\mathrm{n}$ & Sıra ort. & s.d & $\mathrm{X}^{2}$ & $\mathrm{p}$ \\
\hline Biyoloji Öğgretmenliği & 18 & 42.39 & 3 & 23.563 & .000 \\
Fizik Öğretmenliği & 19 & 67.53 & & & \\
Kimya Öğretmenliği & 16 & 76.25 & & & \\
Fen Bilgisi Öğretmenliği & 50 & 41.80 & & & \\
Toplam & 103 & & & & \\
\hline
\end{tabular}

Tablo 9'dan elde edilen sonuçlar fizik, kimya, biyoloji ve fen bilgisi öğretmen adaylarının Soru 3'ten aldıkları puanlar arasında anlamlı bir farklılık olduğunu göstermektedir (X2 (s.d=3, n=103)=23.563, p<.05). Bölümler arasında ortaya çıkan anlamlı farklılığın hangi bölümler arasında ortaya çıktığını belirlemek amacı ile grupların ikili kombinasyonları üzerine "Mann Whitney-U Testi” uygulanmıştır. Bu testten elde edilen sonuçlar aşağıdaki tabloda yer almaktadır.

Tablo 10

Soru 3 için "Mann Whitney-U Testi" Sonuçlarn

\begin{tabular}{|c|c|c|c|c|c|}
\hline Bölüm & $\mathrm{n}$ & Sira Ortalaması & Sira Toplamı & $\mathrm{U}$ & $\mathrm{p}$ \\
\hline Biyoloji Öğretmenliği & 18 & 14.03 & 252.50 & 81.500 & $.006^{*}$ \\
\hline Fizik Öğretmenliği & 19 & 23.71 & 450.50 & & \\
\hline Biyoloji Öğretmenliği & 18 & 11.97 & 215.50 & 44.500 & $.001^{*}$ \\
\hline Kimya Öğretmenliği & 16 & 23.72 & 379.50 & & \\
\hline Biyoloji Öğretmenliği & 18 & 35.39 & 637.00 & 434.000 & .823 \\
\hline Fen Bilgisi Öğretmenliği & 50 & 34.18 & 1709.00 & & \\
\hline Fizik Öğretmenliği & 19 & 16.18 & 307.50 & 117.500 & .252 \\
\hline Kimya Öğretmenliği & 16 & 20.16 & 322.50 & & \\
\hline Fizik Öğretmenliği & 19 & 47.63 & 905.00 & 235.000 & $.001^{*}$ \\
\hline Fen Bilgisi Öğretmenliği & 50 & 30.20 & 1510.00 & & \\
\hline Kimya Öğretmenliği & 16 & 49.38 & 790.00 & 146.000 & $.000^{*}$ \\
\hline Fen Bilgisi Öğretmenliği & 50 & 28.42 & 1421.00 & & \\
\hline
\end{tabular}
${ }^{*} \mathrm{p}<.05$

Tablo 10' da yer alan “Mann Whitney-U Testi” sonuçları incelendiğinde, biyoloji ve fizik öğretmen adayları arasında fizik; biyoloji ve kimya öğretmen adayları arasında kimya; fizik ve fen bilgisi öğretmen adayları arasında fizik; kimya ve fen bilgisi öğretmen adayları arasında kimya öğretmen adayları lehine anlamlı farklılık tespit edilmiştir.

\section{Dördüncü Sınıfta Öğrenim Gören Öğretmen Adaylarının Puanların Karşılaştırılması}

Aşağıda dördüncü sınıfta öğrenim gören öğretmen adaylarının bölümlerine göre soru formunda yer alan her bir soruya ilişkin puanları arasındaki karşılaştırma bulgularına yer verilmiştir.

Dördüncü sınıfta öğrenim gören öğretmen adaylarının soru 1'e ilişkin bulguları. Dördüncü sınıfta öğrenim gören farklı bölümlerdeki öğretmen adaylarının 
Soru 1'den aldıkları puanların karşılaştırılması için uygulanan “illişkisiz Örneklemler için Tek Yönlü Varyans Analizi” sonuçları Tablo 11'de yer almaktadır.

Tablo 11

Soru 1 için "Tek Yönlü Varyans Analizi" Sonuçları

\begin{tabular}{lccccc}
\hline & Kareler Toplamı & s.d & Kareler Ortalamas & F & p \\
\hline Gruplar Arası & 810.563 & 3 & 270.188 & 18.050 & .000 \\
Grup İçi & 1332.233 & 89 & 14.969 & & \\
Toplam & 2142.796 & 92 & & & \\
\hline
\end{tabular}

Tablo 11'den elde edilen sonuçlar incelendiğinde bölümlerin dördüncü sınıflarında öğrenim gören öğretmen adaylarının Soru 1'den aldıkları puanlar arasında istatistiksel olarak anlamlı bir farklılık bulunmuştur $(\mathrm{F}(3,89)=18.050, \mathrm{p}<.05)$. "Tek Yönlü Varyans Analizi” sonrası ortaya çıkan anlamlı farklılığın hangi bölümler arasında olduğunu belirlemek üzere tamamlayıcı "Post-Hoc Analiz Teknikleri"ne geçilmiştir. Öncelikle "Levene Testi” ile grup dağılımlarının varyanslarının homojen olup olmadığı sınanmıştır ve varyansların homojen olduğu belirlenmiştir ( $p>.05$ ). Varyansların homojen olması durumunda yaygınlıkla kullanılan ve alpha tipi hataya karşı duyarlı olan "Scheffe Çoklu Karşılaştırma Tekniği" kullanılmıştır. Bu test sonucu elde edilen veriler Tablo 12' de yer almaktadır.

Tablo 12

Soru 1 için "Post-HocScheffe Testi" Sonuçlar

\begin{tabular}{llcc}
\hline Bölüm (i) & \multicolumn{1}{c}{ Bölüm (j) } & Ortalama Fark1 & $\mathrm{p}$ \\
\hline Biyoloji Öğretmenliği & Fizik Öğretmenliği & -9.454 & $.000^{*}$ \\
& Kimya Öğretmenliği & -6.150 & $.000^{*}$ \\
& Fen Bilgisi Öğretmenliği & -6.699 & $.000^{*}$ \\
\hline Fizik Öğretmenliği & Biyoloji Öğretmenliği & 9.454 & $.000^{*}$ \\
& Kimya Öğretmenliği & 3.304 & .138 \\
& Fen Bilgisi Öğretmenliği & 2.755 & .135 \\
\hline Kimya Ö̆ğretmenliği & Biyoloji Öğretmenliği & 6.150 & $.000^{*}$ \\
& Fizik Öğretmenliği & -3.304 & .138 \\
& Fen Bilgisi Öğretmenliği & -.548 & .971 \\
\hline Fen Bilgisi Öğretmenliği & Biyoloji Öğretmenliği & 6.699 & $.000^{*}$ \\
& Fizik Öğretmenliği & -2.755 & .135 \\
& Kimya Öğretmenliği & .548 & .971 \\
\hline
\end{tabular}

${ }^{*} \mathrm{p}<.05$

Tablo 12 incelendiğinde, "Post-HocScheffe Testi" sonuçlarına göre dördüncü sınıfta öğrenim gören öğretmen adaylarının Soru 1'den aldıkları puanlar açısından Biyoloji $(\bar{x}=4.411$, s.s=2.647) ve Fizik $(\bar{x}=13.866$, s.s=4.323 $)$ öğretmen adayları arasında Fizik; Biyoloji $(\bar{x}=4.411$, s.s $=2.647)$ ve Kimya $(\bar{x}=10.562$, s.s=3.424) öğretmen adayları arasinda Kimya; Biyoloji $(\bar{x}=4.411$, s.s $=2.647)$ ve Fen Bilgisi $(\bar{x}=11.111$, s.s=4.216) öğretmen adayları arasında Fen Bilgisi öğretmen adayları lehine anlamlı farklılık belirlenmiştir.

Dördüncü sınıfta öğrenim gören öğretmen adaylarının soru 2'ye ilişkin bulguları. Dördüncü sınıfta öğrenim gören farklı bölümlerdeki öğretmen adaylarının 
Soru 2' den aldıkları puanların karşılaştırılması için uygulanan "İlişkisiz Ölçümler için Kruskal Wallis H-Testi” sonuçları Tablo 13'te yer almaktadır.

Tablo 13

Soru 2 için "İlişkisiz Ölçümler için Kruskal Wallis Testi" Sonuçları

\begin{tabular}{lccccc}
\hline Bölüm & $\mathrm{n}$ & Sıra ort. & s.d & $\mathrm{X}^{2}$ & $\mathrm{p}$ \\
\hline Biyoloji Öğretmenliği & 17 & 34.00 & 3 & 16.319 & .001 \\
Fizik Öğretmenliği & 15 & 64.13 & & & \\
Kimya Öğretmenliği & 16 & 48.88 & & & \\
Fen Bilgisi Öğretmenliği & 45 & 45.53 & & & \\
Toplam & 93 & & & & \\
\hline
\end{tabular}

Tablo 13'ten elde edilen sonuçlar fizik, kimya, biyoloji, fen bilgisi öğretmen adaylarının Soru 2' den aldıkları puanlar arasında anlamlı bir farklılık olduğunu ortaya koymaktadır $(X 2$ (s.d=3, n=93)=16.319, p<.05). Bölümler arasında ortaya çıan anlamlı farklılığın hangi bölümler arasında ortaya çıktığını belirlemek amacı ile grupların ikili kombinasyonları üzerine "Mann Whitney-U Testi" uygulanmıştır. Bu testten elde edilen sonuçlar Tablo 14'te yer almaktadır.

Tablo 14

Soru 2 için "Mann Whitney U Testi" Sonuçlarn

\begin{tabular}{lccccc}
\hline Bölüm & $\mathrm{n}$ & Sira Ortalamas1 & Sira Toplamı & $\mathrm{U}$ & $\mathrm{p}$ \\
\hline Biyoloji Öğretmenliği & 17 & 12.00 & 204.00 & 51.000 & $.000^{*}$ \\
Fizik Öğretmenliği & 15 & 21.60 & 324.00 & & $.014^{*}$ \\
\hline Biyoloji Öğretmenliği & 17 & 14.50 & 246.50 & 93.500 & $.019^{*}$ \\
Kimya Öğretmenliği & 16 & 19.66 & 314.50 & & .114 \\
\hline Biyoloji Öğretmenliği & 17 & 25.50 & 433.50 & 280.500 & \\
Fen Bilgisi Öğretmenliği & 45 & 33.77 & 1519.50 & & $.004^{*}$ \\
\hline Fizik Öğretmenliği & 15 & 18.43 & 276.50 & 83.500 & .618 \\
Kimya Öğretmenliği & 16 & 13.72 & 219.50 & & \\
\hline Fizik Öğretmenliği & 15 & 40.10 & 601.50 & 193.500 & \\
Fen Bilgisi Öğretmenliği & 45 & 27.30 & 1228.50 & & \\
\hline Kimya Öğretmenliği & 16 & 32.50 & 520.00 & 336.000 &. \\
Fen Bilgisi Öğretmenliği & 45 & 30.47 & 1371.00 & & \\
\hline
\end{tabular}
${ }^{*} \mathrm{p}<.05$

Tablo 14 incelendiğinde, dördüncü sınıfta öğrenim gören biyoloji ve fizik öğretmen adayları arasında fizik; biyoloji ve kimya öğretmen adayları arasında kimya; biyoloji ve fen bilgisi öğretmen adayları arasında fen bilgisi; fizik ve fen bilgisi öğretmen adayları arasında fizik öğretmen adayları lehine anlamlı farklılık tespit edilmiştir.

Dördüncü sınıfta öğrenim gören öğretmen adaylarının soru 3'e ilişkin bulguları. Dördüncü sınıfta öğrenim gören farklı bölümlerdeki öğretmen adaylarının Soru 3'ten aldıkları puanların karşılaştırılması için uygulanan “İlişkisiz Ölçümler için Kruskal Wallis H-Testi" sonuçları Tablo 15'te verilmiştir. 
Tablo 15

Soru 3 için "Kruskal Wallis Testi" Sonuçlarn

\begin{tabular}{lccccc}
\hline Bölüm & $\mathrm{n}$ & Sira ort. & s.d & $\mathrm{X}^{2}$ & $\mathrm{p}$ \\
\hline Biyoloji Öğretmenliği & 17 & 33.79 & 3 & 16.277 & .001 \\
Fizik Öğretmenliği & 15 & 40.67 & & & \\
Kimya Ö̆ğretmenliği & 16 & 69.50 & & & \\
Fen Bilgisi Öğretmenliği & 45 & 46.10 & & & \\
Toplam & 93 & & & & \\
\hline
\end{tabular}

Tablo 15'ten elde edilen sonuçlar fizik, kimya, biyoloji ve fen bilgisi öğretmen adaylarının Soru 3'ten aldıkları puanlar arasında anlamlı bir farklılık olduğunu ortaya çıkarmıştır (X2 (s.d=3, n=93)=16.277, p<.05). Bölümler arasında ortaya çıkan anlamlı farklılı̆̆ın hangi bölümler arasında olduğunu belirlemek amacı ile grupların ikili kombinasyonları üzerine "Mann Whitney-U Testi" uygulanmıştır. Bu testten elde edilen bulgular aşağıdaki tabloda yer almaktadır.

Tablo 16

Soru 3 için "Mann Whitney-U Testi" Sonuçlan

\begin{tabular}{|c|c|c|c|c|c|}
\hline Bölüm & $\mathrm{n}$ & Sira Ortalaması & Sira Toplamı & $\mathrm{U}$ & $\mathrm{p}$ \\
\hline Biyoloji Öğretmenliği & 17 & 15.18 & 258.00 & 105.000 & .389 \\
\hline Fizik Öğretmenliği & 15 & 18.00 & 270.00 & & \\
\hline Biyoloji Öğretmenliği & 17 & 11.21 & 190.50 & 37.500 & $.000^{*}$ \\
\hline Kimya Öğretmenliği & 16 & 23.16 & 370.50 & & \\
\hline Biyoloji Öğretmenliği & 17 & 25.41 & 432.00 & 279.000 & .100 \\
\hline Fen Bilgisi Öğretmenliği & 45 & 33.80 & 1521.00 & & \\
\hline Fizik Öğretmenliği & 15 & 11.10 & 166.50 & 46.500 & $.003^{*}$ \\
\hline Kimya Öğretmenliği & 16 & 20.59 & 329.50 & & \\
\hline Fizik Öğretmenliği & 15 & 27.57 & 413.50 & 293.500 & .448 \\
\hline Fen Bilgisi Öğretmenliği & 45 & 31.48 & 1416.50 & & \\
\hline Kimya Öğretmenliği & 16 & 42.75 & 684.00 & 172.000 & $.002^{*}$ \\
\hline Fen Bilgisi Öğretmenliği & 45 & 26.82 & 1207.00 & & \\
\hline
\end{tabular}

${ }^{*} \mathrm{p}<.05$

Tablo 16'da yer alan sonuçlar incelendiğinde, biyoloji ve kimya öğretmen adayları arasında kimya; fizik ve kimya öğretmen adayları arasında kimya; kimya ve fen bilgisi öğretmen adayları arasında kimya öğretmen adayları lehine anlamlı farklılık tespit edilmiştir.

\section{Öğrencilerin Yanıtlarının Derinlemesine İncelenmesi}

Yukarıdaki bölümlerde araştırma sonuçlarının betimsel incelemesine yer verilmiştir. $\mathrm{Bu}$ bölümde ise öğrencilerin vermiş olduğu yanttlar tek tek okunarak derinlemesine incelenmiştir.

Öğrencilerin ölçme aracının üstkat ve askatlara ilişkin 2. ve 3. sorularına verdikleri yanıtlar karşılaştırıldığında; üçüncü ve dördüncü sınıftaki öğrencilerin, üstkat ve askatların adlarının verildiği soru 3'te, çarpanların verildiği soru 2'ye göre daha yüksek ortalama puanlar aldığı belirlenmiştir. Üçüncü sınıfta öğrenim gören öğrencilerin soru 1'e verdikleri cevaplar incelendiğinde fizik ve fen bilgisi 
öğretmenliği için “kütle”, “uzunluk” ve “zaman”, kimya ve biyoloji öğretmenliği için ise “zaman”, "uzunluk" ve "sıcaklık” en yüksek puan alınan üç temel büyüklüktür.

Dördüncü sınıfta öğrenim gören öğrencilerin soru 1'e verdikleri cevaplar incelendiğinde ise fizik, biyoloji ve fen bilgisi öğretmenliği için "kütle”, "uzunluk" ve "zaman”, kimya öğretmenliği için ise "kütle”, "zaman” ve "sicaklık” en yüksek puan alınan üç temel büyüklüktür. Tüm bölümler için "madde miktarı" ve "aydınlanma şiddeti" ise en düşük puan alınan soru maddeleri olmuştur.

Üçüncü sınıfta öğrenim gören öğrencilerin soru 1'e verdikleri yanlış yanıtlar şu şekildedir; temel büyüklük sembolü olarak uzunluk için " $\mathrm{m}$ "; kütle için " $\mathrm{kg}^{\prime}$; zaman için "s"; sıcaklık için " ${ }^{\circ}$ "; madde miktarı için " $m$ "; elektrik akımı için "A". Ayrıca üçüncü sınıf öğrencileri temel birim adı olarak kütle için "gram"; sıcaklık için "Celcius" ve "santigrat"; 1şık şiddeti için "lümen"; zaman için "dakika"; madde miktarı için "gram"; elektrik akımı için "volt” yazdıkları görülmüştür. Tüm bunlara ek olarak öğrencilerin temel birim sembolü olarak madde miktarı için "m"; kütle için "g"; zaman için "sn"; elektrik akımı için "V"; 1şık şiddeti için "L" cevaplarını ağırlıklı olarak verdikleri görülmüştür.

Dördüncü sınıftaki öğrencilerin 1. soruya verdikleri yanlış cevaplar detaylı olarak incelendiğinde ise temel büyüklük sembolü olarak uzunluk için " $\mathrm{m}$ "; kütle için "kg" ve "gram"; sıcaklık için " $K$ " ve " ${ }^{\circ} \mathrm{C}^{\prime}$; elektrik akımı için " $\mathrm{A}$ "; 1şık şiddeti için " $\Phi$ " cevaplarının ağırlıklı olduğu görülmektedir. Öğrencilerin temel birim adı olarak uzunluğu "santim"; sıcaklığı "santigrat" "derece" ve "Celcius"; kütleyi "gram"; zamanı "dakika"; elektrik akımını "volt"; 1şık şiddetini "amper" ve "watt" olarak ifade ettikleri, temel birim sembolü olarak ise uzunluğa " $\mathrm{cm}^{\prime}$; kütleye "g"; sıcaklığa " ${ }^{\circ} \mathrm{C}$ ";

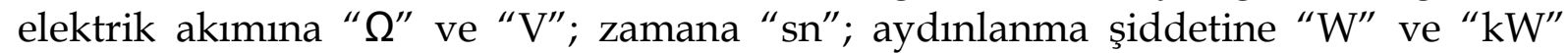
yazdikları tespit edilmiştir.

Üçüncü ve dördüncü sınıfta öğrenim gören öğrencilerin soru 2'ye ait puanları incelendiğinde, biyoloji öğretmenliği hariç tüm bölümlerde ortalama puanların askatlar için üstkatlardan daha yüksek olduğu görülmüştür. Biyoloji öğretmenliğinde bu soruya doğru cevap veren öğrenci olmamıştır. Üçüncü sınıfta öğrenim gören öğrencilerin cevapları detaylı incelendiğinde ise kimya öğretmenliğinde $10^{1}$ ve $10^{2}$ çarpanına ilişkin sembolü, fen bilgisi öğretmenliğinde ise $10^{1}, 10^{2}, 10^{6}, 10^{9}$ ve $10^{12}$ çarpanlarına ilişkin ad ve sembolü doğru cevaplayan öğrenci bulunmadığ görülmüştür. Fen Bilgisi ve kimya öğretmenliğinde en yüksek puan 10-9 çarpanından alınmıştır. Fizik öğretmenliğinde $10^{1}$ ve $10^{12}$ en düşük, $10^{-12}$ ise en yüksek puan alınan ön ekler olmuştur. Dördüncü sınıfta öğrenim gören öğrencilerin cevapları detaylı incelendiğinde ise kimya öğretmenliğinde $10^{-12}, 10^{6}, 10^{9}$ ve $10^{12}$ çarpanlarına ilişkin doğru ad ve sembolü yazan öğrenci bulunmadığı, en yüksek puanın $10^{-3}$ ve $10^{-9^{\prime}}$ dan alındığı görülmüştür. Fizik öğretmenliğinde $10^{-1}, 10^{-2}, 10^{-3}, 10^{1}, 10^{2}, 10^{6}, 10^{9}$ ve $10^{12}$ çarpanlarına ilişkin doğru ad ve sembolü yazan öğrenci bulunmamaktadır ve en yüksek puan alınan madde $10^{-9^{\prime}}$ dur. Fen Bilgisi öğretmenliği bölümünde $10^{3}, 10^{6}$, $10^{9}$ ve $10^{12}$ çarpanlarına ilişkin doğru ad ve sembolü yazan öğrenci bulunmadı̆̆ tespit edilmiştir. Bu soruda en yüksek puan alınan madde ise $10^{-9}$ olmuştur.

Üçüncü sınıfta öğrenim gören öğrencilerin soru 3'e ait puanları incelendiğinde, fizik öğretmenliği hariç tüm bölümlerde ortalama puanların askatlar için üstkatlardan daha yüksek olduğu görülmüştür. Cevaplar detaylı olarak incelendiğinde ise kimya ve fizik öğretmenliğinde "kilo" nun en yüksek, "tera" nın ise en düşük puan alınan ön 
ekler olduğu görülmüştür. Biyoloji öğretmenliğinde en yüksek puan "nano", en düşük puan ise "tera"ve "giga" ön eklerinden alınmıştır. Fen bilgisi öğretmenliğinde ise en yüksek puan "kilo" ve "nano", en düşük puan ise "mega", "tera" ve "giga" ön eklerinden alınmıştır.

Dördüncü sınıfta öğrenim gören öğrencilerin soru 3'ten aldıkları puanlar incelendiğinde, tüm bölümlerde askatlardan alınan ortalama puanların üskatlardan alınan ortalama puanlardan daha yüksek olduğu görülmüştür. Tüm bunlara ek olarak, kimya, fizik ve fen bilgisi öğretmenliğinde "kilo" ve "nano" en yüksek puan alınan ön ekler olmuştur. Kimya öğretmenliği için "deka" ve "tera" ve "giga", fizik öğretmenliği için "deka", "hekto" ve "desi", fen bilgisi öğretmenliği için "tera" ve "giga" en düşük puan alınan ön eklerdir. Biyoloji öğretmenliğinde "nano", "deka" ve "piko" en yüksek, "tera", "mikro" ve "mega" en düşük puan alınan ön eklerdir.

\section{Tartışma, Sonuç ve Öneriler}

Temel bilimler öğretimi için ölçme ve birim sistemleri ünitesi ön koşul özelliği sergilediğinden (Himbert, 2009) fizik kitapları genellikle bu ünite ile başlar (Keller, Gettys ve Skove, 2005; Serway ve Beichner, 2002; Karaoğlu, 2015). Bu nedenle bu araştırmada, eğitim fakültelerinin fizik, kimya, biyoloji ve fen bilgisi öğretmenliği bölümlerinde öğrenim gören öğrencilerin bu ünite içinde yer alan "temel birimler" ve "ön ekler" ile ilgili bilgi düzeyini belirlemek amaçlanmıştır.

Araştırma sonuçları; öğretmen adaylarının "temel birimler" ile ilgili orta düzeyde, “ön ekler" ile ilgili ise düşük düzeyde başarı gösterdiklerini ifade etmektedir. Gelecekte öğretmen olarak görev yapacak ve öğrencilerine temel bilimleri öğretecek olan öğretmen adaylarının bu konular ile ilgili üst düzeyde başarı göstermesi beklenmektedir. Araştırmanın bu sonucu, öğretmenlik bölümlerinde "temel birimler" ve "ön ekler" konuları ile ilgili öğretimin tekrar gözden geçirilmesinin gerekliliğini ifade etmektedir. "Temel birimler" ve "ön ekler" konuları ölçme ve birim sistemleri içinde birinci sınıf temel fizik derslerinde anlatılmaktadır. Burada öğrenilen bilgiler ise laboratuvar derslerinde kullanılmaktadır. Türkiye'de öğretmen eğitimi laboratuvar uygulamaları genellikle doğrulamaya veya ispata dayalı laboratuvar yaklaşımı ile yapılmaktadır (Bilen, Köse ve Uşak, 2011). Bu yaklaşımda laboratuvar eğitimi deneye hazırlık sorularının yer aldığı yazılı veya sözlü bir kısa sınav ile başlanmaktadır. Ardından, deneyin yapılması ve elde edilen verilerin kaydedilerek sonuçlarının rapor haline getirilmesi aşamalarına geçilmektedir (İlhan vd. 2009; Ayas vd. 1997). Öğretmen eğitiminde kullanılan bu laboratuvar yaklaşımı araç gereç yetersizliğinden dolayı dönüşümlü olarak uygulanmaktadır. Bu durum, teorik dersler ile deneylerin paralel yürütülmesini engellemekte ve öğrencilerin öğrenme güçlüğü yaşamasına neden olmaktadır (Ayas vd. 2002). Eğitim fakültesi laboratuvarlarının araç gereç yetersizliğinin giderilerek, her öğrencinin aynı anda aynı deneyi yaptığı ve derslerle deneylerin paralel yürütüldüğü, bir öğretim ortamının (Bilen, Köse ve Uşak, 2011; Güneş vd. 2013) “temel birimler" ve “ön ekler” konusu ile birlikte diğer konuların öğretimine katkı sağlayacağı iddia edilebilir.

Araştırma sonuçları fizik, kimya ve fen bilgisi öğretmen adaylarının "temel birimler" ve "ön ekler" konuları ile ilgili bilgi düzeyinin biyoloji öğretmen adaylarının bu konular ile ilgili bilgi düzeyinden daha yüksek olduğu göstermektedir. Türkiye' de Yüksek Öğretim Kurumu'nun (YÖK) güncellediği fizik ve fen bilgisi öğretmenliği lisans programında fizik ve fizik laboratuvarı dersleri yer almaktadır (Fizik 
Öğretmenliği Lisans Programı, 2018; Fen Bilgisi Öğretmenliği Programı, 2018). Kimya öğretmenliği lisans programında fizik dersi yer almaktadır fakat fizik laboratuvarı dersi yer almamaktadır (Kimya Öğretmenliği Lisans Programı, 2018). Biyoloji öğretmenliği lisans programında ise fizik ve fizik laboratuvarı dersi yer almamaktadır (Biyoloji Öğretmenliği Lisans Programı, 2018). Araştırmaya katılan fizik, fen bilgisi ve kimya öğretmen adayları lisans programlarının güncellenmemiş haline tabi oldukları için fizik ve fizik laboratuvarı derslerini almıştır. Fakat biyoloji öğretmen adayları bu dersleri almamıştır. Bu araştırmada, "temel birimler" ve "ön ekler" konuları ile ilgili biyoloji öğretmen adaylarının diğer öğretmen adaylarına göre daha başarısız olmaları bu durum ile açılanabilir. Biyoloji dersinde kütle, uzunluk ve mol gibi "temel birimler" ile nano seviyeye kadar "ön ekler" skklıkla kullanılmaktadır. Bu durum göz önünde bulundurulduğunda, biyoloji laboratuvarı derslerine ölçme ve birim sistemleri ünitesi eklenerek biyoloji öğretim programında değişiklik yapılması önerilebilir. Ayrıca, kimya öğretmenliği lisans programından fizik laboratuvarı dersinin çıkarılması ilerleyen yıllarda ölçme ve birim sistemleri ile ilgili kimya öğretmen adaylarının da biyoloji öğretmen adayları gibi düşük başarı göstermesine neden olabilir. Bu nedenle, kimya öğretmenliği lisans programına fizik laboratuvarı dersinin tekrar eklenmesi önerilmektedir. Araştırmada ortaya çıkan bir başka sonuç ise fizik ve kimya öğretmen adaylarının bu konular ile ilgili bilgi düzeyinin fen bilgisi öğretmen adaylarının bu konular ile ilgili bilgi düzeyine göre daha yüksek olmasıdır. "Temel birimler" ve "ön ekler" konularının bilim öğretimindeki önemi düşünüldüğünde fen bilgisi öğretmen adaylarının fizik ve kimya öğretmen adayları kadar başarılı olması beklenmektedir. Çünkü öğrencilerin küçük yaşlardan itibaren bu konuları iyi bilmesinin ilerleyen öğretim hayatlarında temel bilimler ile ilgili başarılarını artıracağı iddia edilebilir. Bu nedenle, fen bilgisi öğretmenliğgi fizik laboratuvarı derslerine verilen önemin artırılması önerilebilir. Bu ders tahmin, gözlem ve açıklama yolu ile öğretim yaklaşımları ile zenginleştirilebilir (Ayvacı ve Durmuş, 2016).

Araştırmada öğrencilerin sınıf düzeyi arttıkça biyoloji öğretmen adayları dışındaki öğretmen adayları için "temel birimler" ile ilgili bilgi düzeyinin arttığ1 sonucuna ulaşılmıştır. Bu durum, ülkemizde öğretmen adaylarının mezun olduktan sonra devlet okullarında çalışabilmek için girdikleri Kamu Personeli Seçme Sınavı (KPSS) ile ilişkili olduğu şeklinde yorumlanmıştır. Bu sınavın bir basamağı, Öğretmenlik Alan Bilgisi Testi (ÖABT)'dir. Bu testte öğretmen adaylarının alanları ile ilgili bilgi düzeyi ölçülmektedir. Öğrencilerin bir üst sınıfa geçtiğinde "temel birimler" ile ilgili bilgi düzeyinin artmasında bu sınava çalışmalarının etkisi olduğu düşünülmüştür. Ayrıca, araştırmada öğrencilerin sınıf düzeyi arttıkça çoğunlukla "ön ekler" ile ilgili bilgi düzeylerinin azaldığı veya değişmediği sonucuna ulaşılmıştır. Bu durum, öğretim programlarında sınıf düzeyi arttıkça alan derslerinin ve laboratuvar derslerinin ağırlığının azalmasına bağlı olarak açıklanmıştır. Bu derslerin programdaki ağırlığının azalması öğrencilerin "ön ekler" ile işlem yapma sıklığının azalmasına neden olduğu düşünülmüştür. Bu iki sonuç; öğrencilerin "temel birimler" ve "ön ekler" ile ilgili bilgilerinin kalıcı olmadığını göstermektedir. Öğrencilerin ölçme ve birim sistemleri ile ilgili kalıcı öğrenmesine katkı sağlamak için öğrencilerin araştıran, sorgulayan, inceleyen, günlük hayatla fen konuları arasında bağlantı 
kurmasını sağlayan ders ve laboratuvar etkinliklerine ağırlık verilmesi gerekmektedir (Topuz, vd. 2013).

Araştırmada betimsel istatistik ile elde edilen bulguların yanı sıra öğrencilerin yanıtlarından elde bulgulara da yer verilmiştir. Bu bulgular incelendiğinde, öğrencilerin üstkat ve askatların isimleri verildiğinde çarpanlarını hatırlamada, çarpanları verildiğinde isimlerini hatırlamaya göre daha başarılı oldukları tespit edilmiştir. Bir başka ifade ile öğrenciler üstkat ve askatlar için sayısal büyüklükleri zihinlerinde işlemekte güçlük çekmektedir. Öğrencilerin fizik öğretimi sırasında matematiksel işlemleri yapmada güçlük çektiği bilinmektedir (Şalgam, 2009). Araştırmada ortaya çıkan bu durum, öğrencilerin sayılara karşı oluşturdukları fobi ile ilişkili olarak değerlendirilebilir. Ayrıca araştırmada öğrencilerin temel birimlerin adı, sembolü, birimi ve birim sembollerini karıştırdıkları birbiri yerine kullandıkları anlaşılmaktadır. Temel birimler ile ilgili bu kavramlar ve bu kavramların aralarındaki farklılıkların öğrencilere detaylı olarak açıklanması gerekmektedir. Araştırmada dikkat çeken bir başka bulgu ise öğrencilerin fizik kavramları ile ilgili öğrenme güçlüklerinin birimler ile ilgili öğrenme güçlüklerini etkilemesidir. Örneğin, araştırmaya katılan bazı öğrenciler elektrik akımı için "volt" 1şık şiddetini ise "watt" birimlerini kullanmıştır. Elektrik akımı için elektrik ile ilgili başka bir fiziksel büyüklüğün biriminin kullanılması, 1şık şiddeti için ise başka bir fiziksel büyüklügüun biriminin kullanılması öğrencilerin sahip olduğu kavram yanılgılarının ölçme ve birim sistemleri ile ilgili öğrenmeleri etkilediği şeklinde yorumlanmıştır. Benzer bulgulara başka araştırmacılarda ulaşmıştır. Koray, Özdemir ve Tarar (2005), kütle ve ağırlık kavramlarını karıştıran öğrencilerin bu fiziksel büyüklüklerin birimlerini de karıştırdığını ifade etmiştir. Benzer şekilde Aydoğan, Güneş ve Gülçiçek (2003), 1sı ve sıcaklık kavramlarını karıştıran öğrencilerin bu kavramların her ikisinin de aynı birimle ifade ettiklerini vurgulamıştır.

Araştırmada öğrencilerin askatlarla ilgili soruları üstkatlar ile ilgili sorulara göre daha fazla doğru yaptığı tespit edilmiştir. Bu durum, öğrencilerin laboratuvar deneylerinde askatları üstkatlara göre sık kullanmaları ile açıklanmıştır. Yine benzer şekilde öğrenciler karşılarına sık çıkan as ve üstkatları daha fazla doğru yapmaktadır. $\mathrm{Bu}$ sonuç, ölçme ve birim sistemleri ünitesi için laboratuvar eğitiminin önemini göstermektedir. Benzer şekilde, öğrencilerin "mega", "tera" ve "giga gibi büyük mertebeleri tanımlayan ön ekleri doğru yapma oranlarının düşük olduğu tespit edilmiştir. Hem sınıf hem de laboratuvar ortamında çok sık kullanılmayan bu büyüklüklerin öğrenilmesinde doğrudan deneyimlere dayalı, günlük yaşama ile iç içe yaşam temelli öğrenme etkinlikleri önerilebilir (Özkan ve Selçuk, 2015). Örneğin, bu ön eklerin öğretimi için bilgisayar bellek ölçütleri kullanılarak yaşam temelli öğrenme etkinlikleri oluşturulabilir.

Ölçme ve birim sistemleri ile ilgili öğretimin her kademesinde yapılan araştırma bulguları ile bu araştırmanın bulguları bir arada değerlendirildiğinde ölçme ve birim sistemleri ile ilgili eksik öğrenmelerin sürekliliğinin olduğunu söylenebilir. Bu nedenle, bu ünitenin öğretiminin ilkokuldan üniversiteye birbiri ile ilişkili ve sarmal biçimde ele alınması gerekmektedir. Ayrıca, bu ünitenin öğretimi sırasında öğrencilerin günlük hayatla bağlantı kurmalarını kolaylaştıracak etkinliklere yer verilmesinin öğretimin etkililiğini artıracağı söylenebilir. Bu doğrultuda, bu konu ile ilgili araştırma yapmak isteyen araştırmacılara ilkokuldan, üniversiteye ölçme ve 
birim sistemleri ile ilgili konuların birbiri ve kitaplarda yer alan etkinliklerin günlük hayat ile ilişkisini incelemeleri önerilmektedir. Tüm bunlara ek olarak, araştırmada ortaya çıkan diğer bir konuda öğretmen yetiştirme lisans programlarına eleştirel bir bakışın gerektiği yönündedir (Şişman, 2017). Araştırmacılar, öğretmen yetiştirme lisans programlarını öğretmenlik alan bilgisini kazandırma becerisi açısından inceleyebilir.

\section{Teşekkür}

Bu çalışmanın veri toplama aşamasındaki katkılarından dolayı İbrahim ARI ve Furkan ALBAYRAK'a teşekkür ederiz.

\section{Kaynakça}

Ayas, A., Çepni, S., Turgut, F., Johnson, P. (1997). Kimya öğretimi, YÖK/Dünya Bankası Milli Eğitimi Geliştirme Projesi-Öğretmen Eğitimi Dizisi, Ankara.

Ayas, A., Karamustafaoğlu, S., Sevim, S., Karamustaoğlu, O. (2002). Genel kimya laboratuvarı uygulamalarının öğrenci ve öğretim elemanı gözüyle değerlendirilmesi. Hacettepe Üniversitesi Eğitim Fakültesi Dergisi, 23, 50-56.

Aydoğan, S., Güneş, B., Gülçiçek, Ç. (2003). Isı ve sıcaklık konusunda kavram yanılgıları. Gazi Üniversitesi Gazi Eğitim Fakültesi Dergisi, 23(2), 111-124.

Ayvacı, H. Ş., Durmuş, A. (2016). TGA yöntemine dayalı laboratuvar uygulamalarının fen bilgisi öğretmen adaylarının ısı ve sıcaklık konusunda akademik başarılarına etkisi. Pamukkale Üniversitesi Eğitim Fakültesi Dergisi, 39, 101-118. https:/ / doi.org/10.9779/PUJE742

Bilen, K., Köse, S., Uşak, M. (2011). Tahmin et-Açıkla (TGA) stratejisine dayalı laboratuvar uygulamalarının fen bilgisi öğretmen adaylarının osmoz ve difüzyon konusunu anlamalarına etkisi. Pamukkale Üniversitesi Sosyal Bilimler Enstitüsü Dergisi, 9, 115-127.

BIPM (2006). The International System of Units (SI) (8. Bask1) Erişim adresi: https://www.bipm.org/utils/common/pdf/si_brochure_8_en.pdf.

Bulut, S. (1988). Matematiksel kavramların gelişimi: 5., 7. ve 10. sınıf öğrencileri üzerinde bir araştırma. Ë̆itim ve Bilim, 12, 14-22.

Büyüköztürk, Ş. (2007), Sosyal bilimler için veri analizi el kitabı, Ankara: Pegem A Yayıncilık.

Büyüköztürk, Ş., Çakmak, E.K., Akgün, Ö.E., Karadeniz, Ş. ve Demirel, F. (2010), Bilimsel araştırma yöntemleri (5. baskı). Ankara: PegemA Yayıncılık.

Bragg, P.,Outhred, L. (2004). Students' knowledge of lengthunits: Do they know more than rules about rulers. Proceedings of the 28th Conference of the International Group for the Psychology of Mathematics Education, 2, 159-166.

Davis, R. (2003). The SI unit of mass. Metrologia, 40 (6). 299-305. doi: 10.1088/00261394/40/6/001

Güneş, M. H., Şener, N., Germi, N.T., Can, N. (2013). Fen ve teknoloji dersinde laboratuvar kullanımına yönelik öğretmen ve öğrenci değerlendirmesi. Dicle Üniversitesi Ziya Gökalp Ĕ̆itim Fakültesi, 20, 1-11.

Himbert, M.E. (2009). A brief history of measurement. The European Physical Journal, 172 (Special Topics). 25-35. doi: 10.1140/epjst/e2009-01039-1

İlhan, N., Sadi, S., Yıldırım, A., Bulut, H. (2009). Kimya öğretmen adaylarının laboratuvar uygulamaları hakkındaki görüşleri. Kastamonu Eğitim Dergisi, 17 (1), 153-160. 
Kalın, B.,Arıkıl, G. (2010). Çözeltiler konusunda üniversite öğrencilerinin sahip olduğu kavram yanılgıları. Necatibey Ĕ̈itim Fakültesi Elektronik Fen ve Matematik Ĕ̆itimi Dergisi, 4(2), 177-206.

Karaoğlu, B. (2015). Üniversiteler için fizik. (3. Baskı). Ankara: Seçkin Yayınları.

Keller, F.J.,Gettys, W.E. ve Skove, M.J. (2005). Fizik I. (R.Ö. Akyüz, Çev.). İstanbul: Literatür Yayıncılik.

Koray, Ö., Özdemir, M., Tarar, N. (2005). İlköğretim öğrencilerinin “birimler” hakkında sahip oldukları kavram yanılgıları: kütle ve ağırlık örneği. İlköğretim Online, 4(2), 24-31.

Kuhn, T. S. (1961). The function of measurement in modern physical science. Ists, 52(2), 161-193. doi: 10.1086/349468

Mohr, P. J., Taylor, B. N. (2000). CODATA recommended values of the fundamental physical constants: 1998. Reviews of Modern Physics, 72, 351-495. doi: 10.1103/RevModPhys.72.351

Nassaji, H. (2015). Qualitative and descriptive research: Data type versus data analysis. Language Teaching Research, 19(2), 129-132. doi: $10.1177 / 1362168815572747$

Özdemir, E. (2008). Kuantum fiziğinde belirsizlik ilkesi: Hibrit yaklaşımla öğretimin akademik başarıya etkisi (Yayımlanmamış yüksek lisans tezi). Dokuz Eylül Üniversitesi, İzmir.

Özkan, G. ve Selçuk, G. S. (2015). Kavramsal değişim metinleri ve yaşam temelli öğrenmenin öğrencilerin fizik öğrenme yaklaşımları üzerine etkileri. Mustafa Kemal Üniversitesi Sosyal Bilimler Enstitüsü Dergisi, 12(30), 1-12.

Serway, R. A. ve Beichner R. (2002). Fen ve mühendislik için fizik (K. Çolakoğlu, Çev.). (5. Baskı). Ankara: Palme Yayıncilık.

Şalgam, E. (2009). Fizik öğretiminde probleme dayalı öğrenme yönteminin öğrencilerin akademik başarısılarına ve tutumlarına etkisi (Yayımlanmamış yüksek lisans tezi). Dokuz Eylül Üniversitesi, İzmir.

Şişman, G.T., Aksu, M. (2016). A study on sixth grade students' misconceptions and errors in spatial mesurement: length, area and volume. International Journal of Science and Math Education, 14, 1293-1319. doi: 10.1007/s10763-015-9642-5

Şişman, G.T. (2017). Öğretmen yetiştirme lisans programları ders içeriklerinde "eğitim program1" kavramı. İlköğretim Online, 16(3), 1301-1315.

Topuz, F.G., Gençer, S., Bacanak, A., Karamustafaoğlu, O. (2013). Bağlam temelli yaklaşım hakkında fen ve teknoloji öğretmenlerinin görüşleri ve uygulayabilme düzeyleri. Amasya Üniversitesi Ĕ̆itim Fakültesi Dergisi, 2(1),240261.

Tunzelmann, N., V. (2003). Historical coevolution of governance and technology in the industrial revolutions. Structural Change and Economic Dynamics,14(4), 365384. doi: 10.1016/S0954-349X(03)00029-8

Ünsal, Y., Güneş, B. (2004). Bir kitap inceleme çalışması örneği olarak MEB lise 1. Sınıf fizik ders kitabının eleştirel olarak incelenmesi. Türk Eğitim Bilimleri Dergisi, 2(3), 305-321.

Yıldırım, A., İlhan N. (2007). Lise öğrencilerinin kimya dersinde öğretilen birimler hakkındaki görüşleri ve deneyimleri. Gazi Üniversitesi Gazi Ĕ̆itim Fakültesi Dergisi, 27(3), 211-219. 
Yüksek Öğretim Kurumu (YÖK) Biyoloji Öğretmenliği Lisans Programı. Erişim adresi:https://www.yok.gov.tr/Documents/Kurumsal/egitim_ogretim_dair esi/Yeni-Ogretmen-Yetistirme-Lisans-

Programlari/Biyoloji_Ogretmenligi_Lisans_Programi.pdf

Yüksek Öğretim Kurumu (YÖK) Fen Bilgisi Öğretmenliği Lisans Programı. Erişim adresi:https://www.yok.gov.tr/Documents/Kurumsal/egitim_ogretim_dair esi/Yeni-Ogretmen-Yetistirme-Lisans-

Programlari/Fen_Bilgisi_Ogretmenligi_Lisans_Programi.pdf

Yüksek Öğretim Kurumu (YÖK) Fizik Öğretmenliği Lisans Programı. Erişim adresi:

https://www.yok.gov.tr/Documents/Kurumsal/egitim_ogretim_dairesi/Ye ni-Ogretmen-Yetistirme-Lisans-

Programlari/Fizik_Ogretmenligi_Lisans_Programi.pdf

Yüksek Öğretim Kurumu (YÖK) Kimya Öğretmenliği Lisans Programı. Erişim adresi:https://www.yok.gov.tr/Documents/Kurumsal/egitim_ogretim_dair esi/Yeni-Ogretmen-Yetistirme-Lisans-

Programlari/Kimya_Ogretmenligi_Lisans_Programi.pdf

\section{Ekler}

Ek A. “Temel Birimler ve Ön Ekler Açık Uçlu Soru Formu”

SORU 1. Uluslararası birimler sisteminde (SI) yer alan temel büyüklükler aşağıdaki tabloda yer almaktadır. Tablo'da yer alan temel büyüklüklerin sembollerini, birim adlarını ve birim sembollerini karşısındaki boşluğa yazınız. Lütfen tablodaki boşlukları doldurmadan önce aşağıdaki örneği inceleyiniz.

Örnek

\begin{tabular}{|l|l|l|l|}
\hline Adı & Büyüklüğün Sembolü & Birim Adı & Birimin Sembolü (Kısaltması) \\
\hline Enerji & E & Joule & J \\
\hline
\end{tabular}

\begin{tabular}{|l|l|l|l|}
\hline Temel Büyüklükler & Temel Birim ve Özellikleri & Birimin Sembolü (Kısaltması) \\
\hline Adı & Büyüklüğ̈n Sembolü & Birim Adı & \\
\hline Uzunluk & & & \\
\hline Kütle & & & \\
\hline Zaman & & & \\
\hline Sicaklık & & & \\
\hline Madde Miktarı & & & \\
\hline Elektrik Akımı & & & \\
\hline Işık Şiddeti & & & \\
\hline
\end{tabular}

SORU 2. Uluslararası birimler sisteminde (SI) kullanılan ön eklere ait bazı çarpanlar aşağıdaki tabloda verilmiştir. Tabloda yer alan çarpanların adını ve sembolünü karşısındaki boşluğa yazınız. Lütfen tablodaki boşlukları doldurmadan önce aşağıdaki örneği inceleyiniz.

Örnek

\begin{tabular}{|l|l|l|}
\hline Çarpan & Ad1 & Sembolü (Kisaltması) \\
\hline $10^{-15}$ & femto & f \\
\hline $10^{24}$ & yotta & Y \\
\hline
\end{tabular}

\begin{tabular}{|l|l|l|}
\hline Çarpan & Ad1 & Sembolü (Kisaltması) \\
\hline $10^{1}$ & & \\
\hline $10^{2}$ & & \\
\hline $10^{3}$ & & \\
\hline $10^{6}$ & & \\
\hline $10^{9}$ & & \\
\hline $10^{12}$ & & \\
\hline $10^{-1}$ & & \\
\hline $10^{-2}$ & & \\
\hline $10^{-3}$ & & \\
\hline
\end{tabular}




\begin{tabular}{|l|l|l|}
\hline $10^{-6}$ & & \\
\hline $10^{-9}$ & & \\
\hline $10^{-12}$ & & \\
\hline
\end{tabular}

SORU 3. Uluslararası birimler sisteminde (SI) kullanılan ön eklere ait bazı çarpanların adları aşağıdaki tabloda verilmiştir. Tabloda adı verilen çarpanların sayısal değerini ve sembolünü karşısındaki boşluğa yazınız. Lütfen tablodaki boşlukları doldurmadan önce aşağıdaki örneği inceleyiniz.

\begin{tabular}{|l|l|l|}
\hline Adı & Çarpan & Sembolü (Kisaltması) \\
\hline Femto & $10^{-15}$ & f \\
\hline yotta & $10^{24}$ & Y \\
\hline
\end{tabular}

\begin{tabular}{|l|l|l|}
\hline Ad1 & Çarpan & Sembolü (Kisaltması) \\
\hline deka & & \\
\hline mega & & \\
\hline kilo & & \\
\hline hekto & & \\
\hline piko & & \\
\hline santi & & \\
\hline nano & & \\
\hline tera & & \\
\hline giga & & \\
\hline mikro & & \\
\hline desi & & \\
\hline mili & & \\
\hline
\end{tabular}

\section{Summary}

\section{Introduction}

"Measurement" which is the job of determining the magnitude of a quantity and "units" which define a certain magnitude in terms of quantity are very important for fundamental sciences. An international unit system (SI) has been adopted to standardize measurement. "SI" unit system consists of seven "base units". These units are time (second, s), length (meter, m), mass (kilogram, kg), electric current (amper, A), temperature (kelvin, K), light intensity (candela, cd) and amount of substance (mole, mol). All other units in the "SI" unit system are called derived units. Derived units are formed by the combination of "base units". Understanding the measurement and units is a prior for understanding the physics, chemistry and biology sciences. For this reason, many basic science books, especially physics books, begin with the subject of "Measurement and Unit System". Although the units are a prior for the teaching of basic sciences, a small number of studies on teaching of measurement and unit systems have been found in the literature. In these research, it is emphasized that students from elementary school level to university level have incomplete learning about measurement and unit systems. In this study, knowledge levels of science, physics, chemistry and biology teacher candidates about measurement and unit systems were investigated. For the purpose of the research, answers of the following research questions were searched. (i) What is the knowledge level of the pre-service teachers about "base units" and prefixes? (ii) Is there a difference between the levels of knowledge of "base units" and "prefixes" according to the departments of the teacher candidates in the third year? (iii) Is there a difference between the levels of knowledge of "base units" and "prefixes" according to the departments of the teacher candidates in the fourth year? (iv) Is there a difference between the knowledge level of the preservice teachers in the third and fourth year in terms of "base units" and "prefixes? 


\section{Method}

The descriptive model, which is one of the quantitative research methods, was used to investigate the current situation of teacher candidates related to measurement and unit systems. Convenience sampling was used to determine the sample. In the study, "Unit System Open-ended Questionnaire" was used as data collection tool. This data collection tool contains three questions. First question is about "base units", the second question concerns "prefixes" to the 12 commonly used in "SI" unit system. The third question concerns symbols of these "prefixes". The measurement tool can be found in the Appendix.

The average scores of the students were evaluated in three categories as high, medium and low according to the following table.

Table 1

Rating for success level

\begin{tabular}{lccc}
\hline Question Number & High Level & Medium Level & Low Level \\
\hline $1^{*}$ & $15-21$ & $8-14$ & $0-7$ \\
$2 / 3^{*}$ & $17-24$ & $9-16$ & $0-8$ \\
\hline
\end{tabular}

"The maximum score for question 1 is 21 points. The maximum score for question 2 and 3 is 24 points

In addition, the differences between the scores of the students according to their departments were analyzed with One Way Analysis of Variance (ANOVA) and Kruskal Wallis H Test for Unequal Group Size.

\section{Results and Discussion}

The mean and standard deviation of the students' scores collected by "Unit System Open-ended Questionnaire " are given in the table below.

Table 2.

Average scores and standard deviations of students

\begin{tabular}{lcccccccc}
\hline \multirow{2}{*}{ Department } & Grade & $\mathrm{n}$ & \multicolumn{2}{c}{ Question 1 } & \multicolumn{2}{c}{ Question 2 } & \multicolumn{2}{c}{ Question 3 } \\
\cline { 4 - 9 } & & & Score & s.d & $\begin{array}{c}\text { Average } \\
\text { Score }\end{array}$ & s.d & $\begin{array}{c}\text { Average } \\
\text { Score }\end{array}$ & s.d \\
\hline Biology & 3 & 18 & 7.444 & 3.014 & 0.000 & 0.000 & 3.611 & 2.810 \\
Education & 4 & 17 & 4.411 & 2.647 & 0.000 & 0.000 & 2.411 & 2.152 \\
& $3 / 4$ & 35 & 5.928 & & 0.000 & & 3.011 & \\
\hline Physics & 3 & 19 & 11.210 & 3.425 & 2.421 & 5.699 & 8.578 & 6.039 \\
Education & 4 & 15 & 13.866 & 4.323 & 2.066 & 2.051 & 3.333 & 2.968 \\
& $3 / 4$ & 34 & 12.538 & & 2.244 & & 5.956 & \\
\hline Chemistry & 3 & 16 & 10.437 & 4.381 & 4.500 & 6.077 & 10.187 & 5.729 \\
Education & 4 & 16 & 10.562 & 3.424 & 1.687 & 3.910 & 7.125 & 3.480 \\
& $3 / 4$ & 32 & 10.500 & & 3.094 & & 8.656 & \\
\hline Science & 3 & 50 & 8.460 & 3.124 & 0.540 & 1.417 & 3.860 & 3.714 \\
Education & 4 & 45 & 11.111 & 4.216 & 0.577 & 1.389 & 3.844 & 2.938 \\
& $3 / 4$ & 95 & 9.786 & & 0.559 & & 3.852 & \\
\hline General & $3 / 4$ & 196 & 9.688 & & 2.669 & & 5.369 & \\
\hline
\end{tabular}


When the answers given in Table 2 are examined, it is understood that the average of the scores obtained from question 1 is in the medium success category and the average of the scores obtained from question 2 and question 3 are in the low success category. In addition, it is seen that the average score of the fourth grade teacher candidates from question 1 is higher than the average score of the third grade teacher candidates (except biology teacher candidates). When the average scores obtained from Question 2 are examined, it is seen that the average scores of the teacher candidates (except science teacher candidates) decrease or remain constant as the grade level increased. Finally, when the data obtained from Question 3 is examined, it is seen that the third grade students have a higher average score than the fourth grade students.

The results of students' scores from "One Way Analysis of Variance" and "Kruskal Wallis H Test for Unequal Group Size" according to department and grades are given in the table below.

Table 3.

Comparison of the scores with respect to the department and grade

\begin{tabular}{|c|c|c|c|c|c|c|c|}
\hline \multirow{2}{*}{$\begin{array}{l}\text { Compared } \\
\text { Departments }\end{array}$} & & \multicolumn{3}{|l|}{$3^{\text {rd } G r a d e}$} & \multicolumn{3}{|l|}{$4^{\text {th }}$ Grade } \\
\hline & & Question 1 & Question 2 & Question 3 & Question 1 & Question 2 & Question 3 \\
\hline $\begin{array}{l}\text { Biology } \\
\text { Physics }\end{array}$ & - & Physics & Physics & Physics & Physics & Physics & - \\
\hline $\begin{array}{l}\text { Biology } \\
\text { Chemistry }\end{array}$ & - & - & Chemistry & Chemistry & Chemistry & Chemistry & Chemistry \\
\hline $\begin{array}{l}\text { Biology } \\
\text { Science }\end{array}$ & - & - & Science & - & Science & Science & - \\
\hline $\begin{array}{l}\text { Physics } \\
\text { Chemistry }\end{array}$ & - & - & - & - & - & - & Chemistry \\
\hline $\begin{array}{l}\text { Physics } \\
\text { Science }\end{array}$ & - & Physics & - & Physics & - & Physics & - \\
\hline $\begin{array}{l}\text { Chemistry } \\
\text { Science }\end{array}$ & - & - & Chemistry & Chemistry & - & - & Chemistry \\
\hline
\end{tabular}

When Table 3 is examined, it is seen that physics, chemistry and science teacher candidates are generally more successful than biology teacher candidates in terms of unit systems and "prefixes". In addition, as a result of these comparisons, it is concluded that the most unsuccessful department in terms of "base units" and "prefixes" is biology. In addition, physics and chemistry teacher candidates are more successful than science teacher candidates.

The results of the research indicate that the pre-service teachers have medium level of success in "base units" and a low level of success in "prefixes". It is expected that pre-service teachers, who are teachers of future, will have a high level of success on these issues. The results of the research point out that the curriculum of the teaching departments needs to be revised revised in terms of the unit of measurement and unit systems. The subject of 'Measurement and Unit Systems' is taught in physics course in teaching departments. The knowledge which is learned in this course is applied in the course of physics laboratory. Physics courses are usually taught with direct instructions. The physics laboratory is based on proof based teaching. Students perform an experiment alternately every week. This laboratory curriculum prevents 
active participation of students in the course. In addition, physics courses and physics experiments cannot be taught in parallel with this laboratory curriculum. By strengthening the facilities of physics laboratories, all students can do the same experiment at the same time in parallel with the physics course. In addition, the laboratory teaching program can be based on discovery learning. These changes might contribute to effective teaching of measurement and unit systems.

In the research, it is concluded that pre-service physics, chemistry and science teachers are more successful than biology pre-service teachers. There is no physics and physics laboratory courses in biology teaching curriculum. This can be explained by the fact that biology teacher candidates are more unsuccessful than other teacher candidates. Measurement and unit systems are important for all basic sciences. Therefore, this subject can be added to the biology laboratory course in the biology teaching curriculum. Another result of the research is that physics and chemistry teacher candidates are more successful than science teacher candidates regarding "base units" and "prefixes". Science teacher candidates are expected to be as successful as physics and chemistry teacher candidates. Science teacher candidates will teach science to primary school students in the future. It is important that they know the measurement and unit systems well. For this reason, physics laboratory courses in science teaching curriculum should be given importance as in physics and chemistry teaching curriculums.

In the research, it is concluded that the higher the grade level of the students, the higher the level of knowledge about the "base units". This situation is thought to be the result of the pre-service teachers' studies for the national exam they have taken in order to work as teachers in government schools. In addition, it is concluded that the level of knowledge of "prefixes" decreases or do not change as the grade level of the students increases. This is explained by the fact that the students have taken the physics and physics laboratory courses in the first or second grade.

The results of the research show that the missing learning related to measurement and unit systems is continuous from elementary school to university. For this reason, the teaching of this subject should be handled in a spiral curriculum from primary school to university. In addition, it is thought that it is important to include unit activities related to daily life in teaching this subject. For this reason, it is recommended to examine the curriculum from elementary to university in terms of measurement and unit systems and to evaluate the relevance of the activities related to this subject in the textbooks to daily life.

\section{Araştırmanın Etik Taahhüt Metni}

Yapılan bu çalışmada bilimsel, etik ve alıntı kurallarına uyulduğu; toplanan veriler üzerinde herhangi bir tahrifatın yapılmadığı, karşılaşılacak tüm etik ihlallerde "Cumhuriyet Uluslararası Eğitim Dergisi ve Editörünün" hiçbir sorumluluğunun olmadığı, tüm sorumluluğun Sorumlu Yazara ait olduğu ve bu çalışmanın herhangi başka bir akademik yayın ortamına değerlendirme için gönderilmemiş olduğu sorumlu yazar tarafından taahhüt edilmiştir.

\section{Authors' Biodata/ Yazar Bilgileri}

Mustafa ÇORAMIK Balıkesir Üniversitesi, Necatibey Eğitim Fakültesi, Matematik ve Fen Bilimleri Eğitimi Bölümünde Araş. Gör. Dr. olarak görev yapmaktadır. 
Mustafa Çoramık is working as a Res. Asst. Dr. in Department of Mathematics and Science Education, Faculty of Education in Balıkesir University.

Erdoğan ÖZDEMİR Sivas Cumhuriyet Üniversitesi, Sağlik Hizmetleri Meslek Yüksekokulu'nda Dr. Öğr. Üyesi olarak görev yapmaktadır.

Erdoğan Özdemir is working as a Assist Prof. Dr. in Vocational School of Health Services in Sivas Cumhuriyet University. 